\title{
Origin and variability in volatile organic compounds observed at an Eastern Mediterranean background site (Cyprus)
}

\author{
Cécile Debevec $^{1,2}$, Stéphane Sauvage ${ }^{1}$, Valérie Gros ${ }^{2}$, Jean Sciare ${ }^{3,2}$, Michael Pikridas ${ }^{3}$, Iasonas Stavroulas ${ }^{3}$, \\ Thérèse Salameh $^{1}$, Thierry Leonardis ${ }^{1}$, Vincent Gaudion ${ }^{1}$, Laurence Depelchin ${ }^{1}$, Isabelle Fronval ${ }^{1}$, \\ Roland Sarda-Esteve $^{2}$, Dominique Baisnée ${ }^{2}$, Bernard Bonsang ${ }^{2}$, Chrysanthos Savvides ${ }^{4}$, Mihalis Vrekoussis ${ }^{3,5,6}$, and \\ Nadine Locoge ${ }^{1}$ \\ ${ }^{1}$ Département SAGE, IMT Lille Douai, Université de Lille, Lille, 59000, France \\ ${ }^{2}$ Equipe CAE, Laboratoire des Sciences du Climat et de l'Environnement (LSCE), Unité Mixte CEA-CNRS-UVSQ, \\ Gif sur Yvette, 91190, France \\ ${ }^{3}$ Energy, Environment and Water Research Centre, the Cyprus Institute (CyI), Nicosia, 2121, Cyprus \\ ${ }^{4}$ Department of Labour Inspection (DLI), Ministry of Labour, Welfare and Social Insurance, Nicosia, 2121, Cyprus \\ ${ }^{5}$ Institute of Environmental Physics (IUP), University of Bremen, 28359 Bremen, Germany \\ ${ }^{6}$ Center of Marine Environmental Sciences (MARUM), University of Bremen, 28359 Bremen, Germany
}

Correspondence to: Stéphane Sauvage (stephane.sauvage@imt-lille-douai.fr)

and Cecile Debevec (cecile.debevec@imt-lille-douai.fr)

Received: 28 December 2016 - Discussion started: 14 February 2017

Revised: 4 August 2017 - Accepted: 24 August 2017 - Published: 25 September 2017

\begin{abstract}
More than 7000 atmospheric measurements of over $60 \mathrm{C}_{2}-\mathrm{C}_{16}$ volatile organic compounds (VOCs) were conducted at a background site in Cyprus during a 1-month intensive field campaign held in March 2015. This exhaustive dataset consisted of primary anthropogenic and biogenic VOCs, including a wide range of source-specific tracers, and oxygenated VOCs (with various origins) that were measured online by flame ionization detection-gas chromatography and proton transfer mass spectrometry. Online submicron aerosol chemical composition was performed in parallel using an aerosol mass spectrometer. This study presents the high temporal variability in VOCs and their associated sources. A preliminary analysis of their time series was performed on the basis of independent tracers $(\mathrm{NO}, \mathrm{CO}$, black carbon), meteorological data and the clustering of air mass trajectories. Biogenic compounds were mainly attributed to a local origin and showed compound-specific diurnal cycles such as a daily maximum for isoprene and a nighttime maximum for monoterpenes. Anthropogenic VOCs as well as oxygenated VOCs displayed higher mixing ratios under the influence of continental air masses (i.e., western Asia), indicating that long-range transport significantly contributed to the VOC levels in the area. Source apportionment was then
\end{abstract}

conducted on a database of 20 VOCs (or grouped VOCs) using a source receptor model. The positive matrix factorization and concentration field analyses were hence conducted to identify and characterize covariation factors of VOCs that were representative of primary emissions as well as chemical transformation processes. A six-factor PMF solution was selected, namely two primary biogenic factors (relative contribution of $43 \%$ to the total mass of VOCs) for different types of emitting vegetation; three anthropogenic factors (shortlived combustion source, evaporative sources, industrial and evaporative sources; $21 \%$ all together), identified as being either of local origin or from more distant emission zones (i.e., the south coast of Turkey); and a last factor (36\%) associated with regional background pollution (air masses transported both from the Western and Eastern Mediterranean regions). One of the two biogenic and the regional background factors were found to be the largest contributors to the VOC concentrations observed at our sampling site. Finally, a combined analysis of VOC PMF factors with source-apportioned organic aerosols (OAs) helped to better distinguish between anthropogenic and biogenic influences on the aerosol and gas phase compositions. The highest OA concentrations were observed when the site was influenced by air masses rich in 
semi-volatile OA (less oxidized aerosols) originating from the southwest of Asia, in contrast with OA factor contributions associated with the remaining source regions. A reinforcement of secondary OA formation also occurred due to the intense oxidation of biogenic precursors.

\section{Introduction}

Volatile organic compounds (VOCs) have been known as one of the principal trace constituents in the atmosphere, and they include a large number of species having lifetimes ranging from minutes to months. Their distribution is the result of (1) the release of VOCs to the atmosphere by various natural and anthropogenic sources. Emission by vegetation is regarded as the largest natural source on a global scale (FinlaysonPitts and Pitts, 2000; Guenther et al., 2000). Although anthropogenic emissions are various (Friedrich et al., 1999) and quantitatively smaller than biogenic ones on a global scale (Guenther et al., 2000), anthropogenic VOCs can be the most abundant found in urban areas. Once released into the atmosphere, the temporal and spatial variabilities in VOCs are influenced by (2) mixing processes and (3) removal processes or chemical transformations (Atkinson, 2000; Atkinson and Arey, 2003). Therefore, in order to perform an exhaustive characterization of VOC sources, it is important to know their chemical composition and their potential intensity variations on different timescales.

A robust tool to identify emission sources is positive matrix factorization (PMF - Paatero, 1997; Paatero and Tapper, 1994). Over the last decade, this source receptor approach has been intensively used in urban areas (e.g., Baudic et al., 2016; Salameh et al., 2016; Yuan et al., 2012) and in remote/rural environments (Lanz et al., 2008; Leuchner et al., 2015; Michoud et al., 2017; Sauvage et al., 2009). Other receptor models such as principal component analysis/absolute principal component scores (PCA/APCSs) (Guo et al., 2007), UNMIX (Jorquera and Rappenglück, 2004) and chemical mass balance (CMB) (Badol et al., 2008) have been previously used in VOC source apportionment. Studies show that PMF models are more efficient in identifying source profiles (Jorquera and Rappenglück, 2004). Yuan et al. (2012) stressed the importance of the different reactivity of VOCs and the impact of photochemical aging on the interpretability of the resolved factors as source profiles that have not been considered in most of the studies applying PMF. Therefore, in remote/rural environments, despite the assumption of non-reactivity or mass conservation (Hopke, 2003), PMF can be either used to identify aged primary sources or to get insights into the sources and processes involved in the evolution of measured VOCs (Michoud et al., 2017; Sauvage et al., 2009).
VOCs are also key players in photochemical processes leading to secondary pollutant formation, such as tropospheric $\mathrm{O}_{3}$ (Seinfeld and Pandis, 1998) and secondary oxygenated (O)VOCs (Goldstein and Galbally, 2007; Seco et al., 2007). These latter react with atmospheric oxidants leading to increasingly functionalized products with sufficiently low volatility (Aumont et al., 2012; Jimenez et al., 2009; Kroll and Seinfeld, 2008) taking part in the formation of secondary organic aerosols (SOAs) by nucleation or condensation onto preexisting particles (Fuzzi et al., 2006; Kanakidou et al., 2005). Furthermore, numerical simulation models suggest that the secondary OVOCs are still reactive and multifunctionalized several days after emission, and they thus affect the oxidant budget as well as the formation of ozone and SOA at remote locations (Aumont et al., 2005; Madronich, 2006). It is, therefore, essential to understand the sources and fate of VOCs in the atmosphere and especially their evolution during long-range transport.

The Mediterranean is a sensitive region affected by both particulate and gaseous pollutants. This air pollution is the combination of (1) polluted air masses transported over long distances and originating from three continents (Europe, Asia and Africa - e.g., Lelieveld et al., 2002; Pace et al., 2006 ) with (2) local emissions of anthropogenic origin, associated with local human pressure from the surrounding industrial and densely populated coastal areas of the basin (Im and Kanakidou, 2012; Kanakidou et al., 2011), or natural emissions (Kalogridis et al., 2014; Owen et al., 2001) and forest fires (Bougiatioti et al., 2014). As a consequence, particulate or ozone concentrations are generally higher in the Mediterranean region than in most continental European regions especially during summertime (Doche et al., 2014; Menut et al., 2015; Nabat et al., 2013; Safieddine et al., 2014) since climatic conditions favor the development of photochemical processes (Fountoukis et al., 2011). The Mediterranean region is also considered as a prominent climate change "hot spot", considering interactions between climate and air quality, and is expected to undergo marked warming and drying in the 21st century (Giorgi, 2006; Kopf, 2010; Lelieveld et al., 2014). However, air pollution in this region remains difficult to assess and characterize mostly because of a lack of atmospheric measurements. Additional information on the chemical composition of the air, including the speciation and the reactivity of VOCs, will further improve our current understanding of the complexity of the Mediterranean atmosphere.

In this context, the ChArMEx (the Chemistry-Aerosol Mediterranean Experiment; http://charmex.lsce.ipsl.fr) (Dulac, 2014) international project of the multidisciplinary regional research program MISTRALS (Mediterranean Integrated Studies at Regional and Local Scales; http:// mistrals-home.org) aims to develop and coordinate regional research actions for a scientific assessment of the present and future state of the atmospheric environment in the Mediter- 


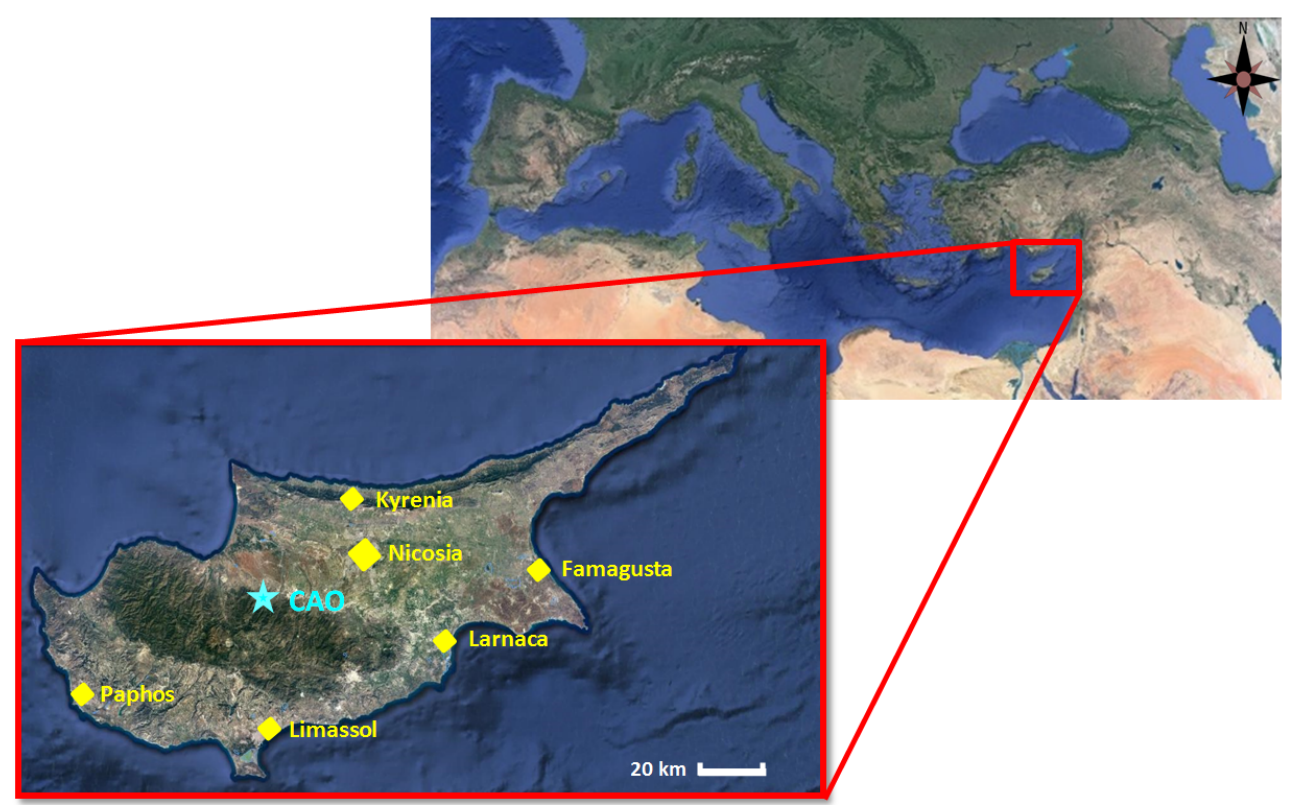

Figure 1. Maps of Cyprus and the Mediterranean region. (a) Position of Cyprus in the Mediterranean region. (b) The sampling site and major Cypriot agglomerations are displayed as a blue star and yellow diamonds, respectively.

ranean basin and of its impacts on the regional climate, air quality and marine biogeochemistry.

The aim of this work is to provide a better characterization of the sources and fate of VOCs impacting the Eastern Mediterranean region, focusing on a comprehensive, high time-resolution, detailed chemical composition measured at a representative receptor site. To reach this objective, online measurements of a large number of VOCs, including alkanes, alkenes, alkyne, aromatics compounds and OVOCs, were performed at the Cyprus Atmospheric Observatory (CAO; http://www.cyi.ac.cy/index.php/cao.html), a receptor site located in Cyprus, in March 2015 within the framework of the ChArMEx and ENVI-Med CyAr (Cyprus Aerosols and gas precursors) programs. The period under investigation offered contrasting conditions in terms of air mass transport (geographical origin, fast/slow transport) and weather (temperature, humidity, precipitations). CAO offers ideal experimental conditions to monitor clean/polluted air masses subject to long-range transport from the three surrounding continents. It is ideally located, close to the coast and far from major Cypriot anthropogenic emission areas. The site is also surrounded by widespread vegetation with intense local biogenic emissions, making possible the investigation of biogenic and anthropogenic interactions on the air mass composition. In the framework of the ChArMEx program, the Western Mediterranean region was already characterized during an intensive field campaign conducted in a French rural site (Cape Corsica) in summer 2013 (Kalogridis, 2014; Michoud et al., 2017). Our study will therefore offer a unique opportunity to characterize VOCs in the Eastern Mediterranean.
First, the sampling site is described in Sect. 2, along with the analytical techniques and the computational tools for identifying and characterizing the major sources of VOCs. In Sect. 3, we investigate VOC levels and their temporal variations in comparison with air quality indicators, meteorological parameters and air mass origins. An accurate identification of PMF factors is proposed in Sect. 3.5. Then, in Sect. 4.1, we compare VOC concentrations measured during this intensive field campaign with previous measurements performed at another background site of Cyprus and factor contributions to source apportionment of VOCs measured at a French remote site in Corsica. Finally, the PMF VOC factors are used in Sect. 4.2 to assess the origin (anthropogenic/biogenic) of non-refractive organic aerosols in $\mathrm{PM}_{1}$ (particulate matter with aerodynamic diameter below $1 \mu \mathrm{m}$ ) measured in parallel.

\section{Material and methods}

\subsection{Sampling site}

Cyprus is an island located on the eastern part of the Mediterranean Sea, $110 \mathrm{~km}$ south of the Turkish coast, ca. $250 \mathrm{~km}$ west of Lebanon and Syria, and $780 \mathrm{~km}$ east of Crete (Greece). This island covers an area of $9250 \mathrm{~km}^{2}$ and includes $648 \mathrm{~km}$ of coastline. The main agglomerations of the island are the capital Nicosia, Limassol, Larnaca, Paphos, Famagusta and Kyrenia (321 816, 176 600, 84 591, 61 986, 50265 and 33207 inhabitants, respectively; census 2011 Fig. 1). Air masses circulating over Cyprus are constrained 
Table 1. Details of techniques and measurements of VOCs from 1 to 29 March 2015.

\begin{tabular}{|c|c|c|c|}
\hline Instrument & GC-FID ChromaTrap & GC-FID AirmoVOC & $\begin{array}{l}\text { PTR-QMS } \\
\text { scan mode } \\
(33-137 \mathrm{amu})\end{array}$ \\
\hline Time resolution (min) & 30 & 30 & 10 \\
\hline Number of samples & 1282 & 1321 & 3879 \\
\hline Temporal coverage $(\%)$ & 94 & 97 & 93 \\
\hline Detection limit $\left(\mu \mathrm{g} \mathrm{m}^{-3}\right)$ & $0.02-0.19$ & $0.03-0.09$ & $0.01-0.24$ \\
\hline $\begin{array}{l}\text { Uncertainties } \frac{U(X)}{X} \\
\text { (min., mean, max.) }(\%)\end{array}$ & $(14,39,73)$ & $(18,36,53)$ & $(18,22,44)$ \\
\hline Species & $9 \mathrm{C}-\mathrm{C}_{5}{ }^{\mathrm{a}} \mathrm{VOCs}$ & $9 \mathrm{C}-\mathrm{C}_{10}{ }^{\mathrm{b}} \mathrm{VOCs}$ & 11 mass $^{\mathrm{c}}$ \\
\hline Reference & Gros et al. (2011) & Xiang et al. (2012) & $\begin{array}{l}\text { Blake et al. (2009); } \\
\text { de Gouw and Warneke (2007); } \\
\text { Taipale et al. (2008) }\end{array}$ \\
\hline
\end{tabular}

\footnotetext{
a Ethane, ethylene, propene, propane, $i$-butane, $n$-butane, acetylene, $i$-pentane and $n$-pentane. ${ }^{\mathrm{b}} 2$-Methylpentane, benzene, toluene, ethylbenzene, $m$ - and $p$-xylenes, $o$-xylene, $\alpha$-pinene and $\beta$-pinene. ${ }^{c} \mathrm{~m} 33$ (methanol), $\mathrm{m} 42$ (acetonitrile), $\mathrm{m} 45$ (acetaldehyde), m59 (acetone), m69 (isoprene), $\mathrm{m} 71$ (MVK + MACR and, eventually, isoprene hydroxy hydroperoxide (ISOPOOH)), m73 (MEK), m79 (benzene), m93 (toluene), m107 (xylenes $+\mathrm{C}_{7}$ species) and m137 (monoterpenes)
}

by two mountain complexes: the Troodos and the Kyrenia Mountains (located in the center and the north of Cyprus, respectively).

Within the framework of two French research programs, ChArMEx and ENVI-Med CyAr, an intensive field campaign was performed at a background site of Cyprus (CAO; $33.05^{\circ} \mathrm{E}-35.03^{\circ} \mathrm{N}$; $532 \mathrm{ma.s.1}$. (above sea level) - Sciare, 2016) from 1 to 29 March 2015. CAO operates under ACTRIS, the European Research Infrastructure for the observation of Aerosol, Clouds and Trace gases (http://actris2.nilu. no/). The station is co-operated by the Department of Labour Inspection (DLI) within the network of the "Co-operative programme for monitoring and evaluation of the long-range transmission of air pollutants in Europe" (EMEP). Therefore, criteria defined by the EMEP and ACTRIS networks provide high quality assurance for the atmospheric measurements performed at CAO. The station is located in the central area of the island about $20 \mathrm{~km}$ from the coast and more than $35 \mathrm{~km}$ from the main Cypriot agglomerations, with limited influence from these anthropogenic emission areas. CAO is situated beside a house of the Cyprus Department of Forests, potentially entailing a local pollution (typical vehicle circulation on week days). In addition, the measurement site is surrounded by widespread vegetation such as maquis, shrubland typical of Mediterranean areas, and oak and pine forests (Fall, 2012), including very large emitters of biogenic (B)VOCs (Owen et al., 2001).

\subsection{Experimental setup}

Figure S1 in the Supplement details the temporal coverage of each instrument deployed during the intensive field campaign presented in this section.

\subsubsection{VOC measurements}

Non-methane hydrocarbons (NMHCs) and OVOCs were measured using complementary online techniques. The inlets were approximately $3 \mathrm{~m}$ a.g.l. (above ground level). Table 1 summarizes the characteristics of the methods performed during the campaign and provides a list of the monitored VOCs.

\section{Gas chromatograph-flame ionization detector}

Two portable automated gas chromatographs (GCs; Chromatotec, Saint-Antoine, France) equipped with a flame ionization detector (FID) were used for online ambient air measurements of $\mathrm{C}_{2}$ to $\mathrm{C}_{10}$ anthropogenic VOCs and $\mathrm{C}_{10}$ BVOCs. The first analyzer, ChromaTrap, allowed the measurement of $\mathrm{C}_{2}-\mathrm{C}_{6}$ hydrocarbons (alkanes, alkenes and alkynes) and the second, AirmoVOC, the measurement of $\mathrm{C}_{6}-\mathrm{C}_{10}$ hydrocarbons (alkanes, monoterpenes and aromatic compounds). For each analysis of $30 \mathrm{~min}, 180 \mathrm{~mL}$ for ChromaTrap and $1320 \mathrm{~mL}$ for AirmoVOC of ambient air was drawn by an external pump through a $0.315 \mathrm{~mm}$ diameter $5 \mathrm{~m}$ length stainless-steel line into the system with a flow rate of $18 \mathrm{~mL} \mathrm{~min}^{-1}$ for ChromaTrap and $60 \mathrm{~mL} \mathrm{~min}^{-1}$ for AirmoVOC. A stainless-steel filter (pore diameter $0.5 \mu \mathrm{m}$, Swagelok) was settled at each inlet to avoid aerosols and other fragments entering the system. Each measurement started with an analysis period, 15 min for ChromaTrap and 19 min for AirmoVOC, and ended with a sampling period, $10 \mathrm{~min}$ for ChromaTrap and $22.5 \mathrm{~min}$ for AirmoVOC. Therefore, instruments were synchronized in order to sample air simultaneously.

Regarding the AirmoVOC analyzer, VOCs were collected by a glass trap filled with adsorbents (Carbotrap B) and maintained at ambient temperature. After sampling, the trap was 
heated rapidly to $380^{\circ} \mathrm{C}$ for $2 \mathrm{~min}$ so that VOCs were thermally desorbed and directly injected into a separating column (MXT30 CE; $30 \mathrm{~m} \times 0.28 \mathrm{~mm}$ diameter) located inside the heated oven of the GC. The oven temperature rose from 38 to $50{ }^{\circ} \mathrm{C}$ with a constant rate of $2{ }^{\circ} \mathrm{C} \mathrm{min}^{-1}$, then with a constant rate of $10^{\circ} \mathrm{C} \mathrm{min}^{-1}$ to $80^{\circ} \mathrm{C}$ and finally with a constant rate of $15^{\circ} \mathrm{C} \mathrm{min}^{-1}$ until the temperature reached $200^{\circ} \mathrm{C}$ at the end of the analysis. An in-depth description of the ChromaTrap analyzer, sampling setup and technical information (pre-concentration, desorption-heating times, type of traps and column types) can be found in Gros et al., 2011. In this study, the oven temperature rose from 35 to $202^{\circ} \mathrm{C}$ with a constant rate of $15^{\circ} \mathrm{Cmin}^{-1}$.

During the campaign, a gas standard containing a mixture of $30 \mathrm{C}_{2}-\mathrm{C}_{10}$ VOCs at a concentration level of $4 \mathrm{ppb}$ (parts per billion by volume) certified by NPL (National Physical Laboratory, Teddington, Middlesex, UK) was injected three times. These series of measurements allowed checking compound retention times, testing the reproducibility of each instrument, and calculating the mean response factor per VOC and per analyzer which was used to calibrate the measurements. The calibration measurements have shown that the analyzer reproducibility (expressed here as a mean coefficient of the variation of the areas obtained) remained stable during the measurement period under investigation with variations within $\pm 5 \%$ for ChromaTrap (except for ethylene and $i$-butane: \pm 9 and $\pm 7 \%$, respectively) and within $\pm 2 \%$ for AirmoVOC. At least two zero-gas measurements were performed consecutively before each calibration to check compound blank values. Detection limits have been determined as being $3 \sigma$ of the baseline and very satisfactory detection limits were found (below 0.2 and $0.1 \mu \mathrm{g} \mathrm{m}^{-3}$ for ChromaTrap and for AirmoVOC, respectively).

Uncertainties related to the concentration of each compound have been estimated. As a first step, the main sources of uncertainties were identified partly based on a quantitative expression relating the value of the measurand to the parameters on which it depends. Each uncertainty arising from these sources was quantified separately and standard uncertainties were combined following the error propagation law. Finally, the expanded uncertainty includes a term proportional to the measurand and a threshold uncertainty (EURACHEM - Ellison and Williams, 2012) as follows:

$U(X)=k \times u(X)+\frac{\mathrm{DL}_{X}}{3}$.

$U(X)$ is the expanded uncertainty in $X, k$ is the chosen coverage factor ( 2 here), $u(X)$ the combined uncertainty in $X$ and $\mathrm{DL}_{X}$ is the detection limit of the species $X$.

In practice, compounds were quantified following the expression given in the ACTRIS Measurement Guidelines VOC, 2014. Identified sources of uncertainties included systematic integration errors (in sample, calibration gas and zero-gas measurements), variability in blank values of VOCs determined in zero-gas measurements, reproducibility and linearity errors of the sampling system, and uncertainty in the standard gas mole fraction. Relative uncertainties in VOCs measured with the ChromaTrap analyzer varied from $14 \%$ (ethane) to $73 \%$ (propene) and from $18 \%$ (benzene) to $53 \%$ (o-xylene) for VOCs measured with the AirmoVOC. Note that compounds measured with the ChromaTrap system showed slightly higher relative uncertainties than ones measured with the AirmoVOC due to their respective blank value which had strong contributions of their variability and integration errors in sample and zero-gas measurements (this concerned mostly propene, $i$-pentane and $n$-pentane).

\section{Proton transfer reaction-quadrupole mass spectrometer}

An online high-sensitivity proton transfer reactionquadrupole mass spectrometer (PTR-QMS; Ionicon Analytik $\mathrm{GmbH}$, Innsbruck, Austria) was used for real-time VOC measurements (e.g., methanol, acetone, isoprene and monoterpenes). Because this instrument has been described in detail in recent reviews (Blake et al., 2009, and references therein), only a brief description of analytical conditions related to ambient air observations is given here.

Ambient air was sampled through a $5 \mathrm{~m}$ long Teflon line (inner diameter: $0.125 \mathrm{~cm}$ ) with a flow rate of $80 \mathrm{~mL} \mathrm{~min}^{-1}$ to minimize residence time to $4 \mathrm{~s}$ inside the sampling line. A filter (pore diameter: $0.5 \mu \mathrm{m}$; Swagelok) was installed at the head of the inlet. The PTR-MS operated at standard conditions: a drift pressure, temperature and voltage of $2.2 \mathrm{mbar}$, $60{ }^{\circ} \mathrm{C}$ and $600 \mathrm{~V}$, respectively, leading to an $E / N$ ratio (corresponding to the electrical field $E$, in $\mathrm{V} \mathrm{cm}^{-1}$, on the buffer gas number density $N$, in molecule $\mathrm{cm}^{-3}$ ) around $130 \mathrm{Td}$. VOC measurements were performed in a full-scan mode and enabled us to browse a large range of masses $(\mathrm{m} / z \quad 30.0$ $m / z 137.0 \mathrm{amu})$. With a dwell time of $5 \mathrm{~s}$ per mass, signals of every mass were acquired every $10 \mathrm{~min}$ and were then normalized to 1 million primary ions as proposed by Warneke et al. (2001). Eleven protonated target masses were considered here (detailed in Table 1), and other masses were used for the assessment of the PTR-MS performances (Dolgorouky, 2012) or as independent parameters.

The PTR-MS background for each mass was daily monitored by sampling zero air generated with ambient air passed through a catalytic scrubber that efficiently removed VOCs via a gas calibration unit (GCU; Ionicon Analytik GmbH, Innsbruck, Austria). Daily background values were then averaged, normalized, linearly interpolated onto all other measurements and subtracted from the atmospheric data before final conversion to mixing ratios.

Three calibrations were performed (before, during and after the intensive field campaign) with the GCU and a standard gas mixture provided by Ionicon and containing 17 VOCs at $1 \mathrm{ppm}$ (parts per million by volume). The instrument response for the species targeted was determined through the measurement of a standard gas previously diluted to mixing ratios in the range of $1-16 \mathrm{ppb}$. Gas calibrations allowed 
us to determine the reproducibility of measurements, expressed here as a mean coefficient of variation. This coefficient was less than $5 \%$ for all targeted compounds underlining a good stability of the instrument. Then, targeted masses were quantified following the expression given in Taipale et al. (2008). For chemicals not found in the calibration gas, their respective ion count rate was directly converted into concentration unit using transmission curve coefficients (de Gouw and Warneke, 2007; Taipale et al., 2008). The latter was determined using the transmission tool of the PTR-MS Viewer software (Version 3.1.0.28, Ionicon Analytik GmbH) and calibration results. Transmission coefficients of masses not calibrated were obtained interpolating known transmission coefficients according to a cubic Hermite spline (Taipale et al., 2008). Detection limits of targeted compounds have been determined as $2 \sigma$ of the blank variation and were all below $0.1 \mu \mathrm{g} \mathrm{m}^{-3}$ except methanol $\left(0.24 \mu \mathrm{g} \mathrm{m}^{-3}\right)$.

Identified sources of uncertainties were the variability in the ion count rates in zero-gas and calibration measurements combined with the dilution, linearity and reproducibility errors of the sampling system, the uncertainty in the standard gas mole fraction, and the relative humidity effect on the instrument sensitivity. Relative uncertainty in VOCs measured with PTR-MS varied from $18 \%$ (acetone) to $44 \%$ (methanol). Uncertainties in VOC concentrations of the gas standard significantly contributed for each targeted species. Additional important contributions were the linearity error and detection limit especially for methanol, acetonitrile, isoprene, methyl vinyl ketone (MVK) + methacrolein (MACR) and $\mathrm{C}_{8}$ aromatics.

\section{Off-line VOC measurements}

More than 400 off-line $3 \mathrm{~h}$ integrated air samples were collected by active sampling on sorbent cartridges (multisorbent and DNPH (2,4-dinitrophenylhydrazine) cartridges). Thirty-nine $\mathrm{C}_{5}-\mathrm{C}_{16}$ anthropogenic VOCs (including alkanes, alkenes and aromatics) and nine BVOCs, as well as six $\mathrm{C}_{6}-\mathrm{C}_{11} n$-aldehydes were collected by multi-sorbent cartridges and analyzed by GC-FID, and $10 \mathrm{C}_{1}-\mathrm{C}_{8}$ carbonyl compounds (e.g., acetone and acetaldehyde) were sampled in parallel on the DNPH cartridges. Samples were after analyzed by GC-FID (for multi-sorbent cartridges) and by HPLC-UV (high-performance liquid chromatography coupled with ultra violet detection - for DNPH cartridges). These techniques have already been described by Detournay et al. (2011) and their setup in the field discussed by Detournay et al. (2013) and Ait-Helal et al. (2014). Here, VOCs measured off-line were used as independent parameters to consolidate the robustness of online measurements by the intercomparison of VOCs measured by different techniques. They will be further presented and investigated in another paper dedicated to biogenic and oxygenated VOCs.

\section{VOC intercomparison}

Benzene and toluene were two compounds measured by different online techniques. Therefore, they were chosen to cross-check the quality of the results during the campaign. Benzene and toluene measured by PTR-MS and GC-FID showed good correlation coefficients $(r=0.75$ and 0.79 for benzene and toluene, respectively; $n=1172$ ) with slopes close to 1 for both compounds ( 0.93 for benzene and 0.87 for toluene) and acceptable intercepts $\left(0.10 \mu \mathrm{g} \mathrm{m}^{-3}\right.$ for benzene and $0.13 \mu \mathrm{g} \mathrm{m}^{-3}$ for toluene). The results from benzene and toluene presented in this paper originated from GC-FID measurements since these instruments were used for a longer time than PTR-MS (January 2015-February 2016). Although the GC-FID method employed can also monitor isoprene, the results presented here originated from PTR-MS due to better sensitivity and analytical performance.

The sum of pinenes measured by the GC-FID was compared to the (non-speciated) monoterpenes measured by PTR-MS, yielding the same variability and consistent ranges of concentrations ( $r: 0.92$; slope: 0.96). The same conclusion was obtained for $\alpha$-pinene, measured by GC-FID and off-line techniques, and acetaldehyde, measured by PTR-MS and off-line techniques. Correlation between online and offline measurements of $\alpha$-pinene and acetaldehyde concentrations displayed good determination coefficients $(r: 0.83$ and 0.90 for $\alpha$-pinene and acetaldehyde, respectively). The slope is also close to 1 for both compounds (1.10 and 1.16 for $\alpha$ pinene and acetaldehyde, respectively). Note that no ozone scrubber was applied to GC systems to prevent any ozonolysis of the measured compounds. However, different ozone scrubbers were used during the sampling of off-line measurements as recommended by Detournay et al. (2011). The consistency of online measurements of $\alpha$-pinene and acetaldehyde with off-line ones, in term of level range and variation, ensured a limited interference of VOC reaction with ozone in results derived from GC measurements.

As a result, the recovery of the different techniques, regular quality checks and an uncertainty determination approach have allowed us to provide a good robustness of the dataset.

\subsubsection{Ancillary gas measurements}

A large set of real-time atmospheric measurements was carried out by the DLI at the CAO, in order to characterize trace gases ( $\mathrm{NO}, \mathrm{NO}_{2}, \mathrm{O}_{3}, \mathrm{CO}$ and $\mathrm{SO}_{2}$ ). They are described in more detail by Kleanthous et al. (2014). The time resolution was $5 \mathrm{~min}$ for each analyzer, but the presented results were provided only at hourly averages.

\subsubsection{Aerosol measurements}

The chemical composition of non-refractory submicron aerosol $\left(\mathrm{NR}-\mathrm{PM}_{1}\right)$ has been continuously monitored using a quadrupole aerosol chemical speciation monitor (Q- 


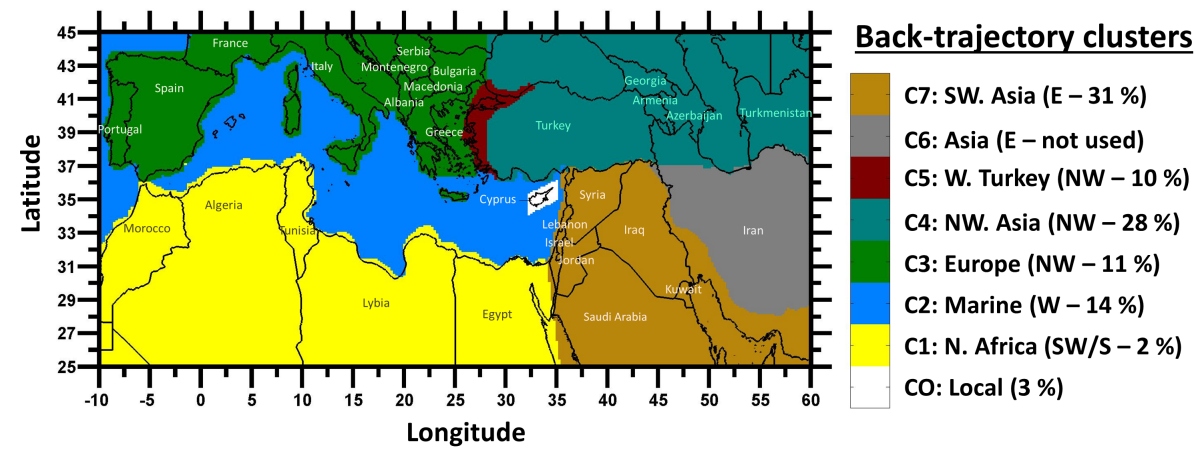

Figure 2. Classification of air masses which impacted the site during the intensive field campaign of March 2015 and their relative contribution. A fraction of $2 \%$ (not shown here) is attributed to air masses of mixed origins.

ACSM; Aerodyne Research Inc., Billerica, Massachusetts, USA), which has been described in detail by Ng et al. (2011). This recent instrument shares the same general structure with the aerosol mass spectrometer (AMS) but has been specifically developed for long-term monitoring. The Q-ACSM instrument operated non-stop with 30 min time resolution during the whole duration of the campaign totalizing 1292 valid data points (corresponding to a time recovery of $95 \%$ ). The ACSM dataset was validated against $\mathrm{PM}_{1}$ chemical composition results provided by integrated daily resolution measurements. Instrument settings, field operation, calibration and data processing are the same as those reported in Petit et al. (2015).

Black carbon (BC) was calculated using the $880 \mathrm{~nm}$ channel of a seven-wavelength $(370,470,520,590,660,880$ and $950 \mathrm{~nm}$ ) Aethalometer (AE31 model, Magee Scientific Corporation, Berkeley, CA, USA) with a time resolution of 5 min. Assuming a difference in the absorption Ångström exponent between fossil fuel and biomass-burning-derived aerosol, the BC origin was distinguished (Sandradewi et al., 2008).

Real-time measurements of particle mass concentrations $\left(\mathrm{PM}_{2.5}\right.$ and $\left.\mathrm{PM}_{10}\right)$ were obtained using a tapered element oscillating microbalance (TEOM 1405-DF, Thermo Scientific, Waltham, Massachusetts, USA) (Clements et al., 2016; Patashnick and Rupprecht, 1991). The time resolution of the TEOM analyzer was $15 \mathrm{~min}$ but the presented results were provided only at hourly averages.

\subsubsection{Meteorological measurement and air mass origins classification}

Meteorological parameters (temperature, pressure, relative humidity, wind speed, wind direction and radiation) were measured every $5 \mathrm{~min}$ with a Campbell Scientific Europe (Antony, France) weather station during the whole campaign.

Classification of air mass origins has been based on the analysis of the retroplumes computed by the FLEXPART Lagrangian model (Stohl et al., 2005) using CAO as the receptor site. The FLEXPART model calculates trajectories of user-defined ensembles of particles released from threedimensional boxes. The classification was based on hourly resolution model simulations going back in time 5 days and taking into account only the lowest $100 \mathrm{~m}$ a.g.l. (footprint plots), even though $3 \mathrm{~km}$ was modeled. The classification of these backward retroplumes involved eight source regions, similar to Kleanthous et al. (2014), identified by a custommade algorithm combined with visual inspection. The source region map is provided in Fig. 2 based on the residence time of particles over each source region.

\subsection{Identification and contribution of major sources of VOCs}

\subsubsection{Source apportionment by PMF}

PMF is a multivariate factor analysis tool for identifying and characterizing the $p$ independent sources of $n$ compounds sampled $m$ times at a receptor site. A more detailed presentation of the PMF mathematical theory is described elsewhere (Paatero and Tapper, 1994; Paatero, 1997). Briefly, the method consists of decomposing chemically speciated sample data into species profiles of each source identified (representing the repartition of each species to each factor) and the amount of mass contributed by each factor to each individual sample (representing the evolution in time of each factor). The principle can be summarized as follows:

$x_{i j}=\sum_{k=1}^{p} g_{j k} \times f_{k i}+e_{i j}=c_{i j}+e_{i j}$,

where $x_{i j}$ is the $i$ th species measured concentration (in $\mu \mathrm{g} \mathrm{m}^{-3}$ here) in the $j$ th sample, $f_{k i}$ the $i$ th mass fraction from the $k$ th source, $g_{j k}$ the $k$ th source contribution of the $j$ th sample, $e_{i j}$ the residual resulting from the decomposition and $c_{i j}$ the reconstructed concentration of the species. The solution of Eq. (2) is obtained iteratively by minimizing the residual sum of squares $Q$ given by Eq. (3):

$Q=\sum_{i=1}^{n} \sum_{j=1}^{m}\left(\frac{e_{i j}}{s_{i j}}\right)^{2}$, 
Table 2. Input information and mathematical diagnostic for the results of PMF analysis.

\begin{tabular}{llr}
\hline Input information & & \\
\hline Samples & $N$ & 1179 \\
Temporal coverage & $M$ & $87 \%$ \\
Species & $P$ & 20 \\
Factors & & 6 \\
Runs & & 100 \\
No. of species indicated as weak & 2 \\
$F_{\text {peak }}$ & & \\
\hline Model quality & $Q(r)$ & 14130.3 \\
\hline$Q$ robust & $Q(t)$ & 14397.5 \\
$Q$ true & & 1.03 \\
$Q(t) / Q$ expected & IM & 0.20 \\
Maximum individual SD & IS & 1.45 \\
Maximum individual column mean & Slope & 1.00 \\
Mean ratio (modeled vs. measured) & (TVOC) & \\
TVOC modeled vs. TVOC measured & $R$ & 0.98 \\
& (TVOC) & \\
No. of species with $R^{2}>0.6$ & & 14 \\
No. of species with $1>$ slope $>0.6$ & & 14 \\
\hline
\end{tabular}

with $s_{i j}$, the extended uncertainty (in $\mu \mathrm{g} \mathrm{m}^{-3}$ ) related to the $i$ th species concentration measured in the $j$ th sample. The PMF tool requires a user-provided uncertainty matrix built upon the procedure described by Polissar et al. (1998) to weight individual points. Results are also obtained using the constraint that no sample can have significantly negative source contributions.

\subsubsection{VOC dataset}

In this present study, EPA PMF 5.0 using a multilinear engine ME-2 (Paatero, 1999) and additional guidance on the use of PMF (Norris et al., 2014) were used to analyze the VOC concentrations observed at CAO. Only online measurements from 1 to 29 March 2015 are taken into account in this factorial analysis. The dataset contains a selection of 20 hydrocarbon species and masses divided into nine compound families: alkanes (ethane, propane, $i$-butane, $n$-butane, $i$-pentane, $n$ pentane, 2-methylpentane), alkene (ethylene), alkyne (acetylene), diene $(m / z 69)$, terpenes (pinenes - sum of $\alpha$-pinene and $\beta$-pinene), aromatics (benzene, toluene, $m / z$ 107), alcohol ( $m / z$ 33), carbonyl compounds $(m / z 45, m / z 59, m / z 71$, $\mathrm{m} 73)$ and nitrile $(m / z 42)$. We chose $m / z 107$ results, measured by PTR-MS, instead of $\mathrm{C}_{8}$ aromatics results, measured by GC-FID, due to their respective uncertainties. Note that same PMF solutions were found if we considered $m / z 137$ instead of the sum of pinenes. The final chemical database consisted of 1179 atmospheric data points with $30 \mathrm{~min}$ time resolution and covering $87 \%$ of the sampling period. PTRMS observations have been averaged to correspond to the
GC-FID time resolution. Input information is summarized in Table 2. Additionally, the PMF approach, regarding data processing and the analysis of the quality of the VOC dataset, is based on the recommendations of Norris et al. (2014) and is presented in the Supplement (Sect. S1).

\subsubsection{Optimized PMF solution}

Several base runs with different numbers of factors were performed initially and examined in order to determine the optimal number of factors following the protocol proposed by Sauvage et al. (2009). The selection of the optimal solution relies on several statistical indicators and the physical meaning of factor profiles. The non-negativity constraint alone is not sufficient to produce a unique solution generally. Rotating a given solution and evaluating the rotated results with the initial solution is one approach to reduce the number of solutions. Thus, the second step consisted of exploring the rotational freedom of the PMF solution kept by varying the $F_{\text {peak }}$ parameter (Paatero et al., 2002, 2005) in order to determine an optimized final solution. Therefore, a six-factor PMF solution has been selected and an $F_{\text {peak }}$ parameter of 0.8 allowed a better decomposition of the chemical dataset with a low change in the $Q$ value, consistent with the recommendations of Norris et al. (2014).

Quality indicators from the PMF application have been summarized in Table 2. The ratio $\mathrm{Q}$ (robust) $/ \mathrm{Q}$ (true) reached a value around 1.0 indicating that the modeled results were not biased by peak events. The PMF model results explained on average $98 \%$ of the total concentration of the 20 VOCs. Individually, almost all the chemical species also displayed both good determination coefficients and slopes (close to 1) between predicted and observed concentrations, with the exception of species declared as weak and propane, acetylene, toluene and acetonitrile. Therefore, the limitations of the PMF model to simulate these species should be kept in mind when interpreting the PMF results.

Rotational ambiguity and random errors in a PMF solution were evaluated using DISP (displacement) and BS (bootstrap) error estimation methods (Norris et al., 2014; Paatero et al., 2014; Brown et al., 2015). No factor swap occurred in the DISP analysis results, thus indicating that the six-factor PMF solution was sufficiently robust to be used. Bootstrapping was then carried out, executing 100 runs, using a random seed, a block size of 97 samples and a minimum Pearson correlation coefficient of 0.6. All the modeled factors were well mapped over at least $85 \%$ of runs, hence highlighting their reproducibility. 


\subsection{Geographical origins of VOCs}

\subsubsection{Local pattern of VOC sources using a conditional probability function}

The geographical locations associated with VOC sources can be approached using a conditional probability function (CPF; Ashbaugh et al., 1985) as performed in several studies (Gaimoz et al., 2011; Kim et al., 2003, 2005; Xiang et al., 2012; Xie and Berkowitz, 2006, 2007). Source contributions were combined for that purpose with wind direction values measured on site in order to identify the geographical orientation of sources. Specifically, the CPF is defined as

$$
\mathrm{CPF}=\frac{m_{\Delta \theta}}{n_{\Delta \theta}},
$$

where $m_{\Delta \theta}$ is the number of samples in the wind sector $\Delta \theta$ that exceeded the threshold criterion and $n_{\Delta \theta}$ is the total number of samples in the wind sector considered. As done by Kim et al. (2003), relative contributions from each source to the total of all sources was used to minimize the effect of atmospheric dilution. In this study, wind directions were binned into eight sectors of $45^{\circ}$ and the threshold was set at the upper 75th percentile of all relative contributions for each source to measure the frequency at which a peak occurred under a specific wind direction. Calm winds with speeds of less than $1 \mathrm{~m} \mathrm{~s}^{-1}$ were excluded from the calculations, which represented $8 \%$ of the total observations. Additionally, the CPF analysis makes sense only if air arriving at a receptor site has traveled on a relatively straight path from the source. While this assumption is probably true for receptors and sources that are quite close to each other, it is not generally the case in particular for background receptor sites which are far from local sources. Therefore, CPF has shown the likely local orientation of potential sources, and straight paths can be selected using $6 \mathrm{~h}$ back trajectories to simplify the analysis (Zhou et al., 2004; Xie and Berkowitz, 2006).

\subsubsection{Identification of potential regional emission areas using the concentration field}

Since wind measured at a receptor site is not necessarily representative of the initial origin of the air mass, source contributions were then coupled with back trajectories to investigate potential long-distance pollutions advected to the sampling site. In this study, we have used the concentration field (CF) approach developed by Seibert et al. (1994). This method consists of redistributing concentrations of a variable observed at a receptor site along the back trajectories, ending at this site, inside a gridded map. Attributed concentration in a cell is then weighted by the residence time that air parcels spent in the cell following Eq. (5) (Michoud et al., 2017):

$\log \left(\overline{C_{i j}}\right)=\frac{\sum_{L=1}^{M} \log \left(C_{L}\right) \times n_{i j-L}}{\sum_{L=1}^{M} n_{i j-L}}$

$$
=\frac{1}{n_{i j}} \sum_{L=1}^{M} \log \left(C_{L}\right) \times n_{i j-L},
$$

with $\overline{C_{i j}}$ being the attributed concentration of the $i j$ th grid cell, $C_{L}$ the concentration measured at the receptor site when the back trajectory $L$ reached it, $n_{i j-L}$ the number of points of the back trajectory $L$ which fall in the $i j$ th grid cell and $n_{i j}$ the number of points of the total number of back trajectories $M$ associated with the cell concerned.

The 5-day back trajectories used, along with meteorological parameters (i.e., precipitation), were calculated every $1 \mathrm{~h}$ using a PC-based version of the HYSPLIT Lagrangian model (version 4.4 revised in February 2016; Draxler and Hess, 1997; Stein et al., 2015). The altitude of the end point was set at $800 \mathrm{~m}$ a.s.l., respectively. The constant time step between each point of a back trajectory is $1 \mathrm{~h}$.

$\mathrm{CF}$ applied to PMF results was performed with the ZeFir tool (version 3.02; Petit et al., 2017). As done by Bressi et al. (2014), wet deposition was estimated by assuming that precipitation $(0.1 \mathrm{~mm})$ will clean up the air parcel. The $\log \left(C_{\mathrm{L}}\right)$ value was set to 0 for all air parcels of the backtrajectory path before precipitation occurred. Back trajectories have also been interrupted when the altitudes of air masses exceeded $1500 \mathrm{~m}$ a.s.l. to get rid of the important dilution affecting the air masses when reaching the free troposphere (Michoud et al., 2017). Furthermore, in order to consider air parcels with a good representativity, a weighing function has been implemented to remove high CF uncertainties usually linked with low $n_{i j}$ values. The method implemented in ZeFir was based on a "trajectory density" $\log \left(n_{i j}+1\right)$ (Bressi et al., 2014; Waked et al., 2014). Indeed, weighing function is empirically determined as

$$
W=\left\{\begin{array}{ll}
1.00, & \text { for } n_{i j} \geq 0.85 \max \left(\log \left(n_{i j}+1\right)\right) \\
0.725, & \text { for } 0.85 \max \left(\log \left(n_{i j}+1\right)\right)>n_{i j} \\
& \geq 0.6 \max \left(\log \left(n_{i j}+1\right)\right) \\
0.475, & \text { for } 0.6 \max \left(\log \left(n_{i j}+1\right)\right)>n_{i j} \\
& \geq 0.35 \max \left(\log \left(n_{i j}+1\right)\right) \\
0.175, & \text { for } 0.35 \max \left(\log \left(n_{i j}+1\right)\right)>n_{i j}
\end{array},\right.
$$

where $\max \left(\log \left(n_{i j}+1\right)\right)=3.67$ or $\max \left(n_{i j}+1\right)=4657$ in this study. Finally, the spatial coverage of the grid cells is set from $17.5^{\circ} \mathrm{E}, 30^{\circ} \mathrm{N}$ to $40^{\circ} \mathrm{E}, 41^{\circ} \mathrm{N}$, with a grid resolution of $0.1^{\circ} \times 0.1^{\circ}$. To take into account the uncertainties regarding the back-trajectory path, a smoothing of attributed contributions was applied as recommended by Charron et al. (2000) using a smooth factor (i.e., the strength of a Gaussian filter) of 5 .

\section{Results}

\subsection{Air mass origin and meteorological conditions}

In March 2015, weather conditions were characterized by varying hourly temperatures, ranging from 8 to $24^{\circ} \mathrm{C}$ with 


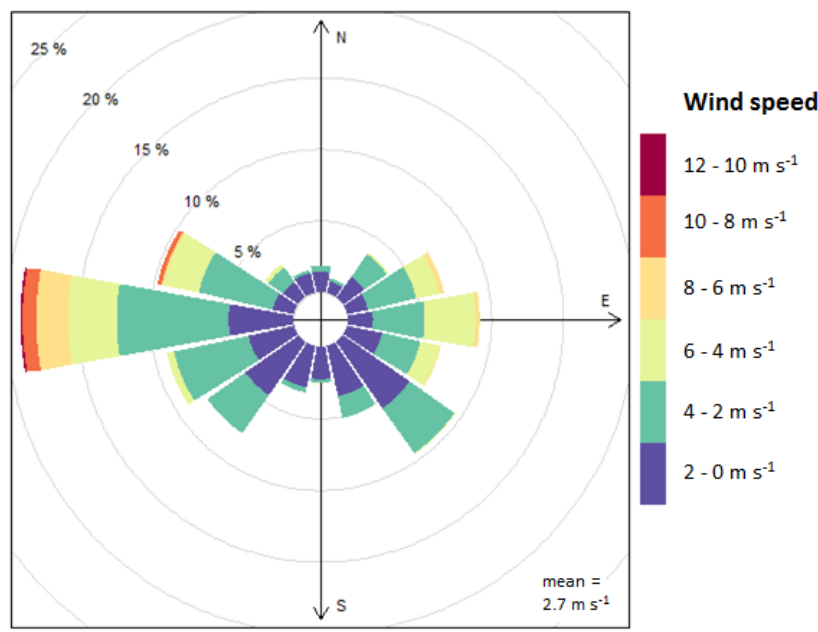

Figure 3. Wind rose of March 2015. Contribution expressed in percent corresponds to the frequency of counts by wind sector.

an average of $13 \pm 3{ }^{\circ} \mathrm{C}$. The most favorable conditions for high biogenic VOC emissions (high temperatures, clear skies and low winds) were observed from 8 to 10 March and from 25 to 27 March. Some rough-weather days, characterized by lower temperatures, heavy rain and strong winds, also occurred (11-14, 20-22 and 28 March) and rainy periods may contribute to a larger development of vegetation. Throughout the campaign, the wind speed showed a large degree of variability, reaching up to $13 \mathrm{~m} \mathrm{~s}^{-1}$ (20-22 March) and favoring the dispersion of pollutants. In the days with low winds favoring stable conditions, wind speed was below $2 \mathrm{~m} \mathrm{~s}^{-1}$. Due to the two mountains ranges, wind was blowing mainly from western directions with a wind speed of up to $13 \mathrm{~m} \mathrm{~s}^{-1}$ (only observed in this wind sector) (Fig. 3).

Figure 2 shows the respective contribution of air mass origins observed during the campaign. The $\mathrm{CAO}$ station was mostly influenced by continental air masses originating from southwest Asia (cluster $7-31 \%$ ), northwest Asia (cluster 4 $-28 \%$ ), the west of Turkey (cluster $5-10 \%$ ) and Europe (cluster $3-11 \%$ ) but also by marine air masses (cluster $2-$ $14 \%$ ). Note that air masses categorized as "local" (cluster 0) occurred only on 23 and 24 March and may rather be considered as a transitory state between periods of air masses originating from northwest Asia and the west of Turkey. It is worth noting that March 2015 was characterized by an unusually high contribution of southwest Asian air masses and a low contribution of European air masses unlike the period 1997-2012 presented in Kleanthous et al. (2014). In this study, "local origins" will refer to contributions from Cyprus and "regional origins" to air masses originating from the Mediterranean region. However, long-range transport contributions cannot be easily separated from local contributions. Indeed, winds blowing from east and southeast directions could lead to local influence from Larnaca and its surroundings and were observed when air masses originated from $\mathrm{Eu}-$ rope, northwest Asia and southwest Asia (Fig. S2). Likewise, a second local anthropogenic influence may come from the Nicosia region corresponding to situations where the winds were observed in the northeast direction and to air masses originating from northwest Asia and southwest Asia.

\subsection{Atmospheric background conditions}

Time series of gases ( $\mathrm{NO}, \mathrm{NO}_{2}, \mathrm{CO}$ and $\mathrm{O}_{3}$ ) and aerosol tracers $\left(\mathrm{PM}_{2.5}, \mathrm{PM}_{10}\right.$ and $\mathrm{BC}$ split into $\mathrm{BC}_{\mathrm{ff}}$ and $\mathrm{BC}_{\mathrm{wb}}$ originating from fossil fuels and wood burning, respectively) are shown in Figs. S3 and S4.

NO levels remained low (below $0.3 \mathrm{ppb}$ ) during the whole campaign indicating a weak influence from directly surrounding sources. Likewise, the average $\mathrm{NO}_{2}$ concentration was $0.9 \mathrm{ppb}$ and peaks of concentration higher than $3 \mathrm{ppb}$ were only encountered three times during the intensive field campaign ( 9,18 and 28 March). CO concentrations were in the range of 80-230 ppb with highest levels encountered on 10 March when the station received continental air masses originating from southwest Asia. Levels of $\mathrm{O}_{3}$ varied from 25 to $60 \mathrm{ppb}$, with the highest levels encountered on 9-10 and 25-27 March. These periods correspond to the warmest days but also to air masses originating from northwest and southwest Asia, especially from the south of Turkey, an area characterized by intense anthropogenic emissions of ozone precursors (see Sect. 3.5.2).

$\mathrm{BC}_{\mathrm{ff}}$ was largely dominating ( $95 \%$ of $\mathrm{BC}$ ), which suggested $\mathrm{BC}$ was almost exclusively emitted from fossil fuel combustion. $\mathrm{BC}_{\mathrm{wb}}$ levels remained low during the whole campaign $\left(<0.2 \mu \mathrm{g} \mathrm{m}^{-3}\right)$ indicating no significant wood burning event during the campaign. BC $30 \mathrm{~min}$ average levels increased (up to $2.2 \mu \mathrm{g} \mathrm{m}^{-3}$ ) when the station was under the influence of continental air masses (northwest Asia and the west of Turkey) corresponding to the warmest days of the period. Higher concentrations of $\mathrm{PM}_{2.5}$ and $\mathrm{PM}_{10}$ were noticed when the station received air masses originating from the southwest (concentrations up to 30 and $60 \mu \mathrm{g} \mathrm{m}^{-3}$, respectively). Among other influences, $\mathrm{PM}_{2.5}$ and $\mathrm{PM}_{10}$ concentrations were below 20 and $25 \mu \mathrm{g} \mathrm{m}^{-3}$, respectively.

\subsection{VOC mixing ratios}

Twenty-four different VOCs were measured online during the campaign. These compounds were classified as belonging to three major families: biogenic, anthropogenic and oxygenated VOCs (3, 15 and 6 measured VOCs, respectively). Biogenic compounds included only isoprene and monoterpenes, while anthropogenic compounds only included primary hydrocarbons (alkanes, alkenes, alkynes and aromatic compounds) almost exclusively emitted from human activities. As OVOCs come from biogenic and anthropogenic (primary and secondary) sources, they have been presented separately. Statistical analysis, uncertainties and detection limits 
of the VOC measurements are presented in Table S1 in the Supplement.

Anthropogenic VOCs were the most abundant (49\% of the total concentration of the measured VOCs) and were mainly composed of $\mathrm{C}_{1}-\mathrm{C}_{5}$ compounds $(76 \%$ of the anthropogenic VOCs) but also of aromatics compounds (8\%). Biogenic compounds were mainly composed of monoterpenes $(84 \%$ of the total concentration of BVOCs) and had a small contribution to the total VOCs on average (about $5 \%$ ). With an average contribution of $46 \%$ of the measured VOCs, OVOCs were mainly composed of methanol and acetone (47 and $33 \%$ of the total concentration of OVOCs, respectively).

An overview of VOC concentrations observed at different background locations in the Mediterranean is presented in Table 3. Anthropogenic VOC levels measured here were in the range of those measured at the rural/marine/remote sites of Cape Corsica (France), Finokalia (Greece) and Messorougion (Greece) during fall and winter with the exception of ethane and propane that were higher at CAO. Concerning biogenic compounds, as for $\mathrm{CAO}$, the Cape Corsica and Finokalia sites are typical Mediterranean shrublands, and isoprene concentrations measured at these sites during wintertime were of the same order of magnitude. Additionally, CAO seemed to present a higher contribution of monoterpenes in comparison with other comparable sites (e.g., Ínia, Cape Corsica and Valderejo). OVOC concentrations observed during the campaign were also in the same range as observed for the other Mediterranean sites but lower than summer campaign values (e.g., Ínia and Cape Corsica).

\subsection{VOC variabilities}

\subsubsection{Anthropogenic compounds}

As expected for combustion tracers, $\mathrm{CO}$ covaried well with acetylene, a long-lived anthropogenic species (Fig. 4). These two compounds exhibited higher levels when the station was influenced by air masses imported from northwest and southwest Asia. Additionally, $i$-butane, a typical marker for evaporative sources, covaried well with $\mathrm{BC}$, another tracer of combustion processes suggesting they may be emitted by a common source point (e.g., a traffic source including gasoline evaporation and exhaust emissions). Higher $i$-butane mixing ratios were observed when the site was under continental influence (from 6 to 11 March) suggesting an additional contribution from more distant sources (regional origins). Shortlived compounds (propene and ethylene) covaried suggesting a common local combustion source, even though a tendency to increase was observed only for propene when the station was influenced by continental air masses (6-11 March), indicating a potential additional contribution from more distant sources.

\subsubsection{Biogenic compounds}

Results from two biogenic tracers (isoprene and $\alpha$-pinene) are presented in Fig. 5. Their distinct diurnal pattern suggests that these compounds may not be emitted by the same biogenic source. The observed isoprene pattern followed the typical diel profile, which depends on environmental parameters (temperature and solar radiation - Geron et al., 2000; Owen et al., 1997). Indeed, isoprene concentrations increased immediately at sunrise, indicative of local biogenic sources. Higher concentrations were also observed during the warmest days of the campaign (8-10 March) with a maximal temperature of $24^{\circ} \mathrm{C}$. Isoprene presented high concentrations also during the nights of 8 and 10 March. Surprisingly, $\alpha$-pinene concentrations were more elevated during the nighttime compared with daytime. A similar nocturnal pattern has been observed elsewhere (Harrison et al., 2001; Kalabokas et al., 1997; Kalogridis et al., 2014) and was attributed to nocturnal emissions from monoterpenes storing plants from the understory vegetation. These nocturnal maxima were enhanced by the shallow nocturnal boundary layer and the slow removal processes (i.e., low concentrations of oxidizing species) leading to higher concentrations.

\subsubsection{Oxygenated compounds}

With atmospheric lifetimes ranging from a few hours to several days, OVOCs can be emitted both from primary sources (mainly biogenic but also anthropogenic) and be produced by secondary processes related to the oxidation of anthropogenic and biogenic hydrocarbons. In Fig. 6, OVOCs present diurnal variabilities with large amplitudes when the temperature increased (9-12 March), suggesting a local biogenic contribution but also a potential secondary one (i.e., favorable conditions for photochemical processes). During the same period, the increase in background levels could be associated with a distant source of assumed anthropogenic origin in combination with high contribution of anthropogenic compounds of different lifetimes (see Sect. 3.4.1). Nocturnal variabilities were also observed, although not systematically, and coincided with an increase in temperature as observed during an intensive field campaign at Cape Corsica (Kalogridis, 2014). Possible interpretations would be linked to a dynamical phenomenon and a reinforcement of biogenic emissions.

\subsection{Source apportionment of VOCs}

In the following section, the six-factor PMF solution (from simulations described in Sect. 2.3) is presented and discussed. Figure 7 shows the contributions of each factor to the species selected as input for the PMF model as well as the contribution of each species to the six factors determined by the PMF analysis. Figure 8 shows the time series of the six PMF factor contributions. In this section, life- 
Table 3. Comparison of mean concentrations of selected VOCs with ambient levels observed in the literature in the Mediterranean region from different atmospheres. Concentrations are expressed in $\mu \mathrm{g} \mathrm{m}^{-3}$.

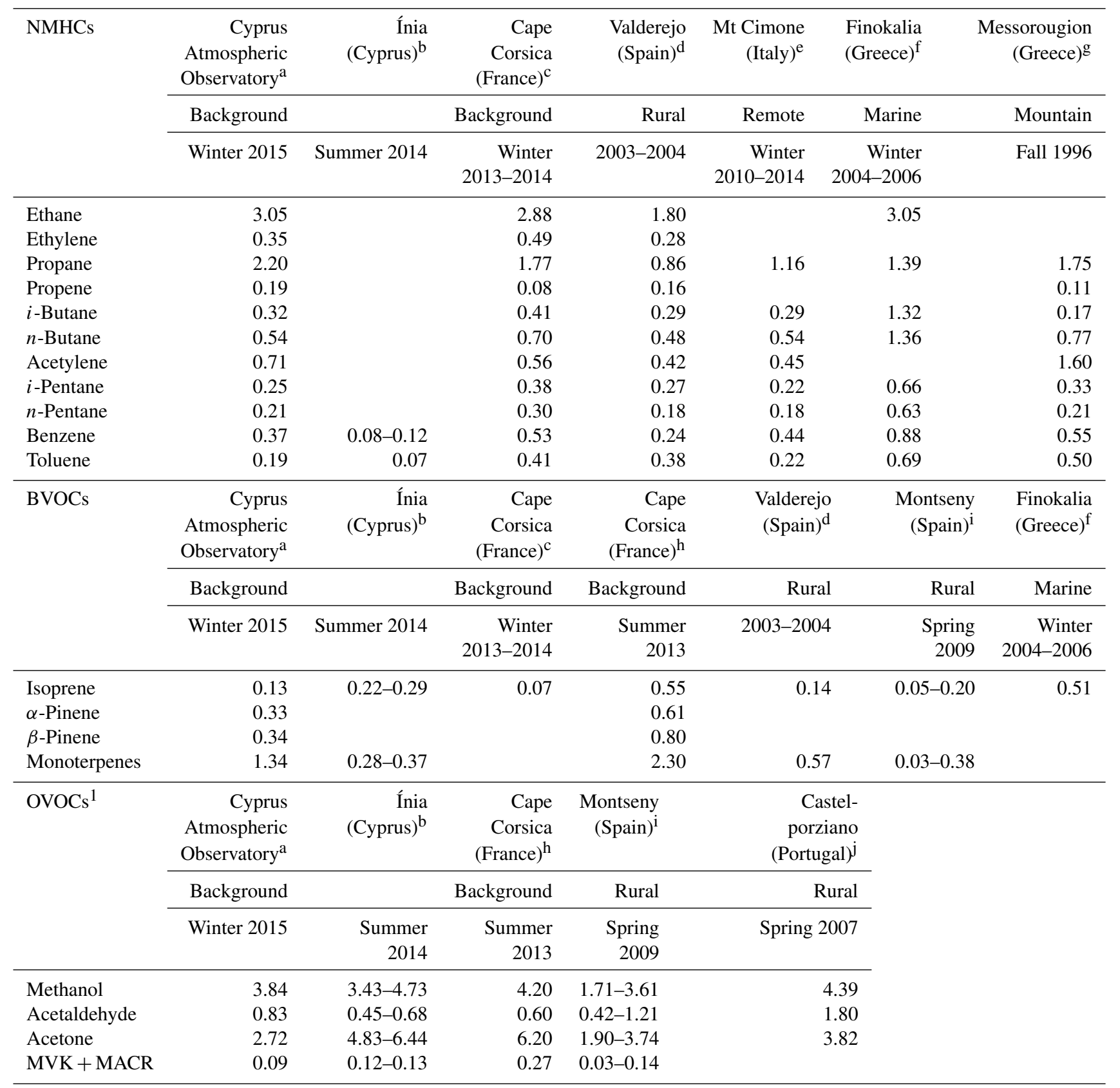

${ }^{1}$ VOCs measured by PTR-MS. ${ }^{a}$ this study. ${ }^{\mathrm{b}}$ Derstroff et al. (2016). ${ }^{\mathrm{c}}$ ChArMEx database. ${ }^{\mathrm{d}}$ Navazo et al. (2008). ${ }^{\mathrm{e}}$ Lo Vullo et al. (2016). ${ }^{\mathrm{f}}$ Liakakou et al. (2007, 2009).

g Moschonas and Glavas (2000). ${ }^{\mathrm{h}}$ Michoud et al. (2017); Kalogridis (2014). ${ }^{\mathrm{i}}$ Seco et al. (2011). ${ }^{\mathrm{j}}$ Davison et al. (2009).

times were estimated from kinetic rate constants of the reactions between the species of interest and $\mathrm{OH}$ (Atkinson and Arey, 2003) considering an average $\mathrm{OH}$ concentration of $1.0 \times 10^{6}$ molecules $\mathrm{cm}^{-3}$ (Spivakovsky et al., 2000). Concerning isoprene and monoterpenes, we also considered their kinetic rate constants of their reaction with ozone (Atkinson and Arey, 2003) with an average daily measured $\mathrm{O}_{3}$ concen- tration of $1.7 \times 10^{12}$ molecules $\mathrm{cm}^{-3}$ to estimate their lifetime.

VOCs result from direct emissions, chemistry, transport and mixing, and therefore each individual factor cannot be attributed exclusively to one source category. Some of the computed factors may not be directly related to emission profiles but should rather be interpreted as aged profiles originating from different sources belonging to similar source categories 


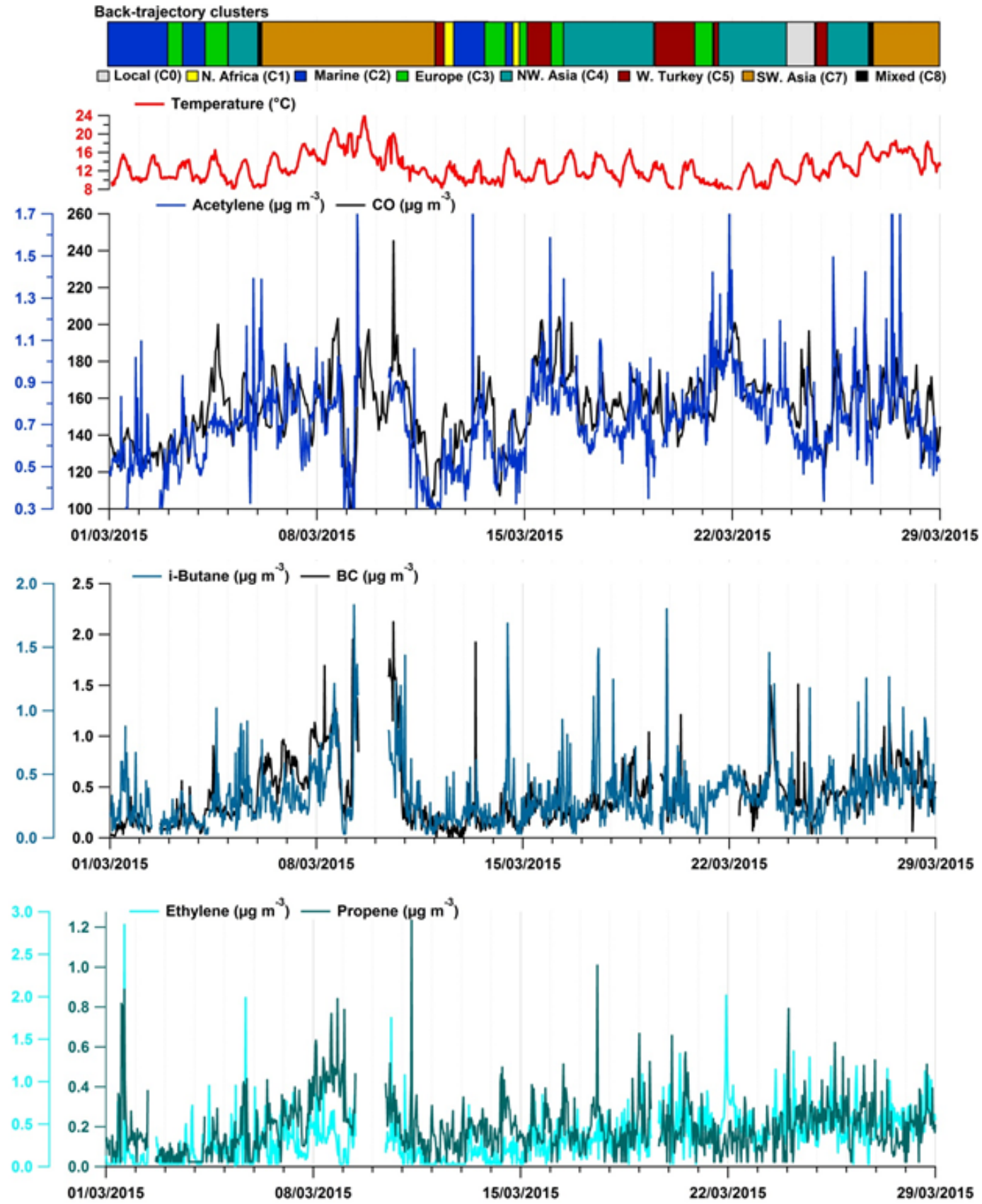

Figure 4. Time series of a selection of anthropogenic VOCs (acetylene, $i$-butane, ethylene and propene - blue lines) in comparison with air mass origin, meteorological parameters (temperature displayed as red lines) and air combustion tracers (CO and BC - black lines).

(Sauvage et al., 2009). PMF was conducted to identify covariation factors of VOCs that were representative of aged or local primary emissions as well as secondary photochemical transformations occurring during the transport of air masses sampled at this background site (Michoud et al., 2017).

\subsubsection{Biogenic factors with distinct origins (factors 1 and 2)}

Two biogenic factors were identified: "biogenic source 1" and "biogenic source 2". They are both composed of primary biogenic species but have shown distinct variabilities and origins justifying the division into two factors. Figure 9 shows the diurnal cycle of the biogenic factors along with meteorological parameters (temperature and solar radiation). CPF 


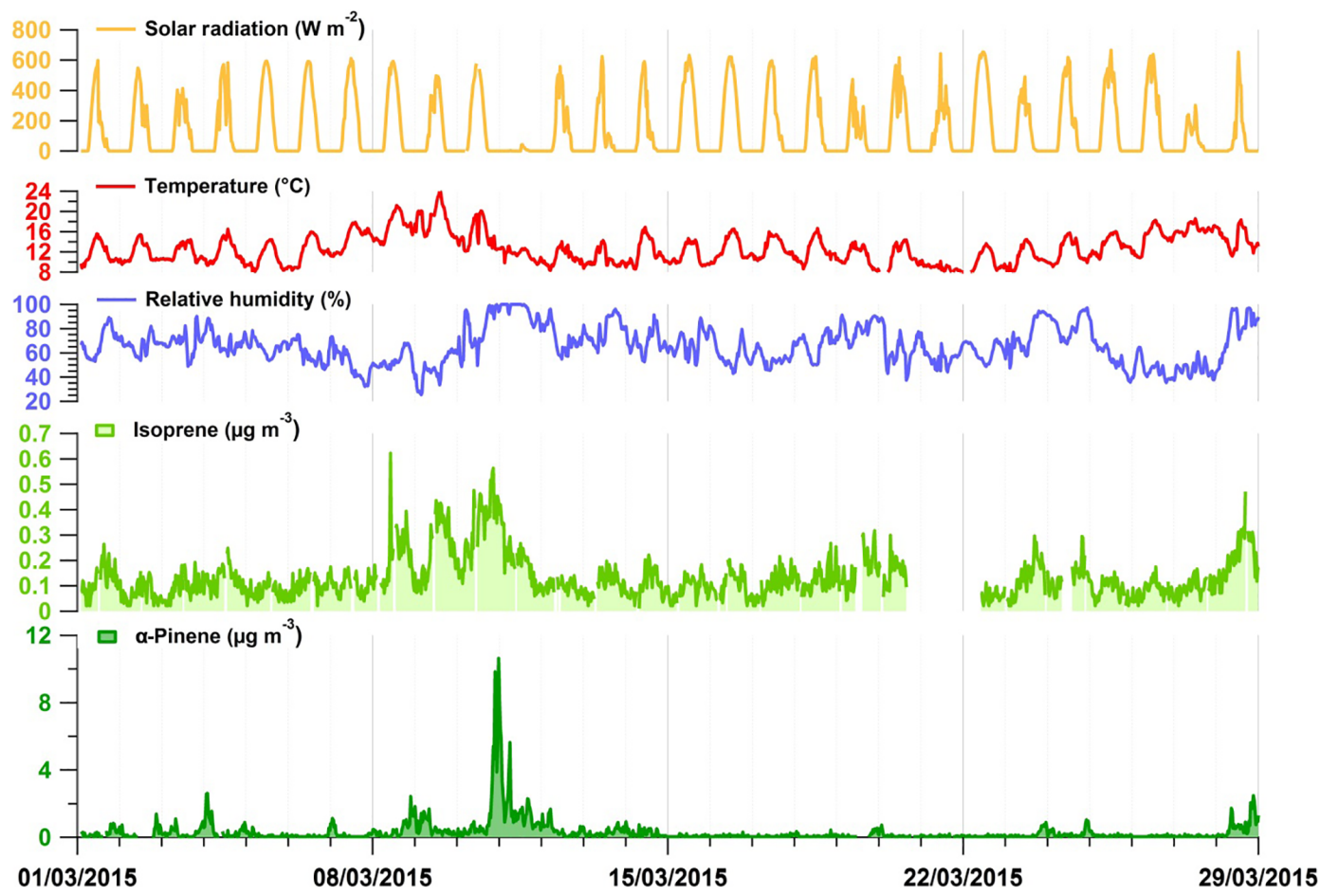

Figure 5. Time series of a selection of biogenic VOCs (isoprene and $\alpha$-pinene - green lines) in comparison with meteorological parameters (solar radiation, temperature and relative humidity; displayed as orange, red and blue lines, respectively).

results of these factors are also investigated and are presented in Fig. S5.

The average contribution of the biogenic source 1 factor is only $1.3 \mu \mathrm{g} \mathrm{m}^{-3}(7 \%)$ during the studied period due to its few episodic contributions. Indeed, from 8 to 12 March, its relative contribution reaches $63 \%$ of the total VOC mass (Fig. 8) with peaks up to $34.8 \mu \mathrm{g} \mathrm{m}^{-3}$. This biogenic event occurred during the warmest period, with diurnal temperatures reaching up to $24^{\circ} \mathrm{C}$. The biogenic factor 1 explains $100 \%$ of the variability in pinenes, and the relative load of these species for this factor is $55 \%$. The lifetime of $\alpha$-pinene and $\beta$ pinene in the troposphere was quite short $(1.4$ and $2.8 \mathrm{~h}$, respectively), indicating that these compounds were emitted exclusively by local vegetation. In addition, a few OVOCs (methanol and acetone mainly) are also found in this profile. The contribution of these compounds to factor 1 is estimated at $21 \%$. These OVOCs are also known to be partly emitted from biogenic emission sources (Jacob et al., 2002; Schade et al., 2011; Schade and Goldstein, 2001; Seco et al., 2007; Singh et al., 2004). The diurnal profile of factor 1 exhibits higher contributions during the nighttime (18:00-05:00 LT, local time) (in agreement with the diurnal variability in $\alpha$ pinene investigated in Sect. 3.4.2), and CPF analysis localizes this source in the south and southwest directions from the sampling site, which were mainly encountered during the nighttime (Fig. S2). In these directions, the area corresponds to pine and/or oak forests (Fig. S5 - Fall, 2012), known to be high emitters of pinenes but also of OVOCs (e.g., acetone; Janson and de Serves, 2001). As a result, air masses observed at $\mathrm{CAO}$ during the nighttime were enriched during transport over oak and pine forests with biogenic nocturnal emissions from plants with BVOC storage compartments, like coniferous species (Laothawornkitkul et al., 2009; Niinemets et al., 2004). These nocturnal maxima were also enhanced by the slow removal processes (i.e., low concentrations of oxidizing species) and the shallow nocturnal boundary layer.

With an average contribution estimated to be $6.1 \mu \mathrm{g} \mathrm{m}^{-3}$, this factor, biogenic source 2 , is one of the two main VOC factors observed during March 2015 at CAO, explaining $36 \%$ of TVOC (i.e., the sum of the $n$ species including in the initial dataset of the PMF model - see Sect. S1 in the Supplement). Factor 2 is mainly composed of OVOCs, such as methanol (77\% explained), acetaldehyde ( $84 \%$ explained), acetone (50\% explained) and MEK (methyl ethyl ketone) (59\% explained). The total contribution of these oxygenated compounds to factor 2 is $79 \%$, with more than $42 \%$ attributed to methanol. Most of these species are formed by the oxidation of both anthropogenic and biogenic compounds although some of them can also have a primary origin (e.g., the MEK budget described in Yáñez-Serrano et al., 2016, and the acetaldehyde budget in Millet et al., 2010; Seco et al., 2007). Additionally, this factor profile includes isoprene ( $82 \%$ explained), a known chemical marker of primary biogenic emissions with a short lifetime $(2.3 \mathrm{~h})$, and its pri- 

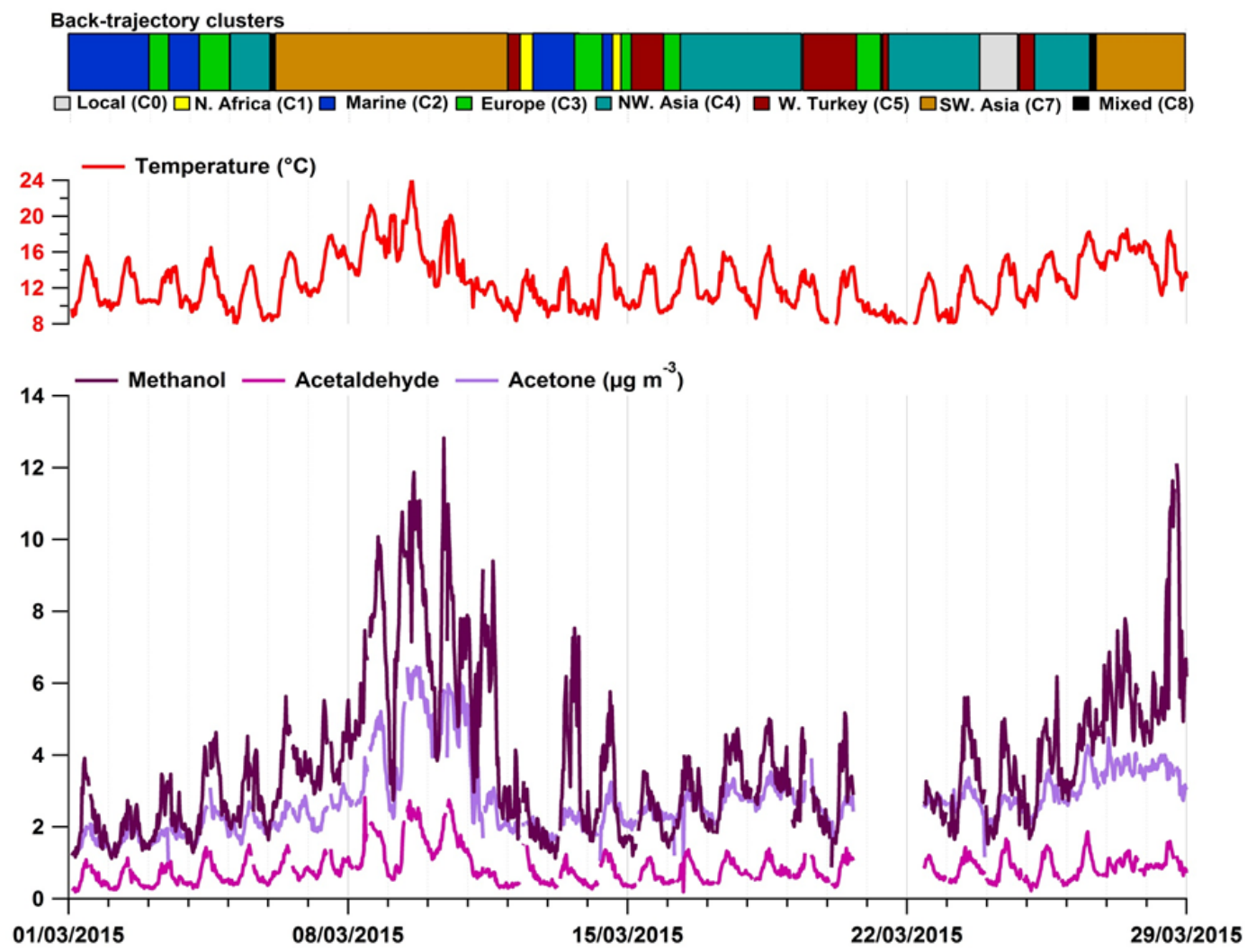

Figure 6. Time series of a selection of OVOCs (methanol, acetaldehyde and acetone - purple lines), temperature (red line) and air mass origin clustering.

mary oxidation products (Spaulding et al., 2003): MACR and MVK (77\% explained; lifetime of 9.6 and $13.8 \mathrm{~h}$, respectively). Its diurnal profile exhibits a clear temperature and solar radiation dependency (Fig. 9), as already observed for isoprene in Sect. 3.4.2. Individually, oxygenated species have shown the same daily variation as isoprene and its oxidation products, confirming their direct link. In conclusion, factor 2 is also attributed to a biogenic source (mainly driven by isoprene emissions), while factor 1 is characterized by pinenes. Small amounts of $\mathrm{C}_{1}-\mathrm{C}_{6}$ alkanes are also found in this profile with a cumulated contribution to factor 2 of $12 \%$ and can be attributed to a mixing with other temperature-related sources or artefacts from the PMF model (Leuchner et al., 2015). CPF analysis of factor 2 localizes the corresponding biogenic emission area in the northwest to the northeast directions from the sampling site with associated distinct land covers: "garrigues" and "other land" (Fig. S5) corresponding mainly to cultivated areas.

\subsubsection{Anthropogenic factors (factors 3,4 and 5)}

Among the six identified PMF factors, three were attributed to anthropogenic sources (factors 3, 4, and 5) and were characterized by compounds of various lifetimes.
Firstly, we note that these three anthropogenic factors showed enhanced contributions and similar variations during the periods when the station was influenced by air masses imported from southwest Asia (i.e., 6 to 12 and from 26 to $29 \mathrm{March})$. These periods were also associated with enhanced levels of the anthropogenic compounds investigated in Sect. 3.4.1 but also $\mathrm{C}_{6}-\mathrm{C}_{14}$ alkanes and fossil fuel combustion tracers ( $\mathrm{CO}, \mathrm{NO}_{2}$ and $\left.\mathrm{BC}\right)$. These indications suggest that anthropogenic VOCs were potentially of the same origin when the station was influenced by air masses from southwest Asia and this independently of their specific sources. To determine the potential origin of these anthropogenic events observed at $\mathrm{CAO}$, the $\mathrm{CF}$ results, concerning the factor contributions associated with southwest Asian air masses alone (Fig. S6), were investigated. These results pinpoint the southeast coast of Turkey as a potential origin of these anthropogenic events observed at CAO. This region corresponds to densely populated areas of Turkey (including Adana and Gaziantep, with more than 1.6 million of inhabitants, the fifth and the sixth most densely populated cities in Turkey, respectively) with expected high anthropogenic emissions due to intense industrial and maritime activities (e.g., the seaport of Mersin) and a dense road network. The conclusion is that southwest Asian air masses were associated with higher contributions of all the three primary anthropogenic 

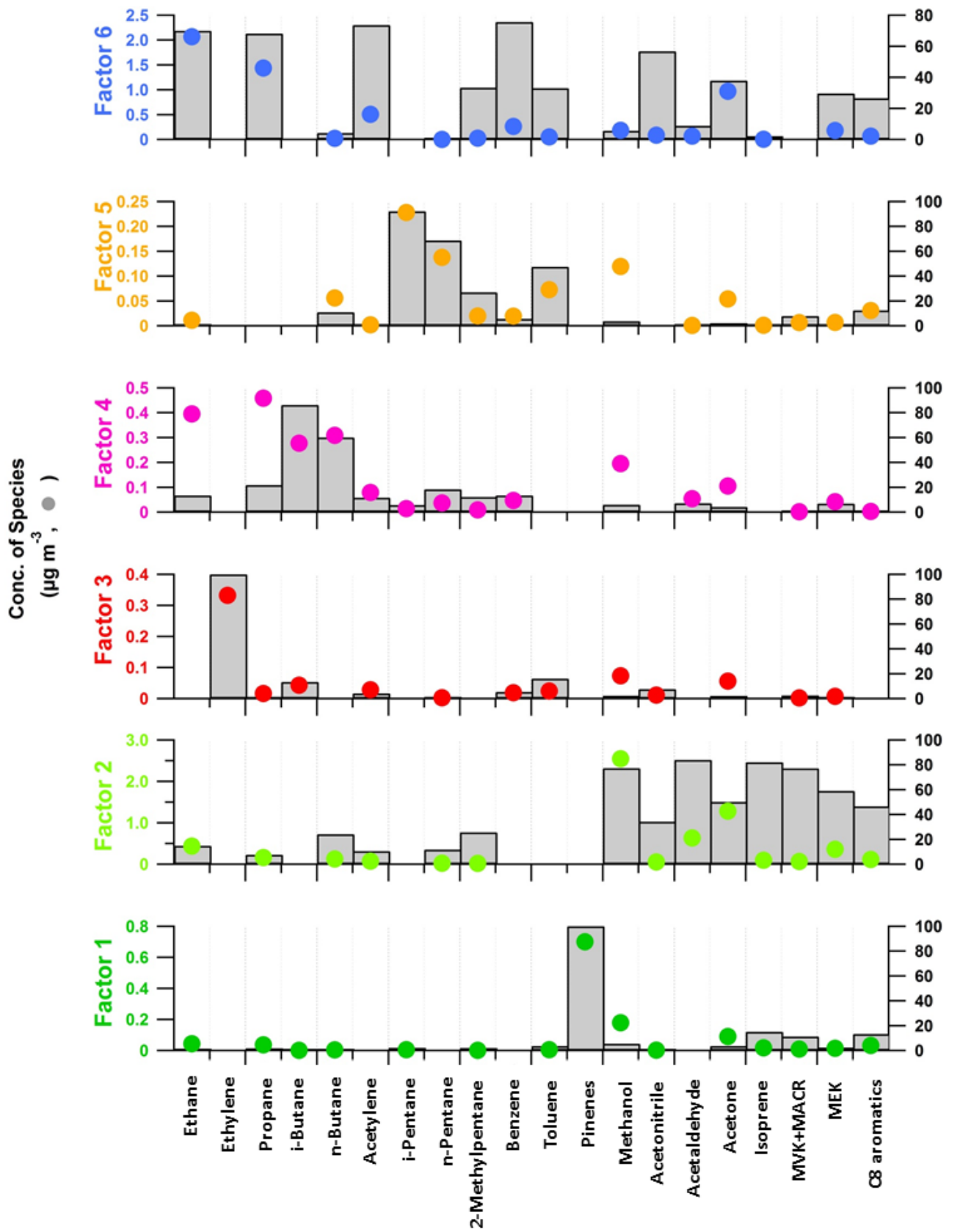

Figure 7. Chemical profiles of the six-factor PMF solution (20 VOCs). The contribution of the factor to each species $\left(\mu \mathrm{g} \mathrm{m}^{-3}\right.$ ) and the percent of each species apportioned to the factor are displayed as a grey bar and a colored circle, respectively. Factor $1-$ biogenic source 1 ; factor 2 - biogenic source 2; factor 3 - short-lived combustion source; factor 4 - evaporative sources; factor 5 - industrial and evaporative sources; factor 6 - regional background.

VOC factors. Therefore, to study each of these three anthropogenic factors and their additional local/regional origins more specifically, they will be investigated in the rest of this section, omitting the contributions associated with southwest Asian air masses. Diel variabilities are shown in Fig. 10. CPF results were also investigated and are presented in Fig. 11.

Factor 3 only represents up to $4 \%$ of the sum of measured VOCs. This factor is composed of primary anthropogenic
VOCs, ethylene (100\% explained) and toluene (14\%), typical compounds of incomplete combustion processes with short to medium lifetime (1.4 and 2 days, respectively), with a total contribution to this factor of up to $55 \%$. Factor 3 displays fair correlation with ethylene $(r=0.94)$ and seems to correlate with $\mathrm{NO}_{2}, \mathrm{CO}$ and $\mathrm{BC}$, which are known to be relevant vehicle exhaust markers $(r=0.41,0.40,0.37$, respectively). Even if the diurnal profile does not exhibit 


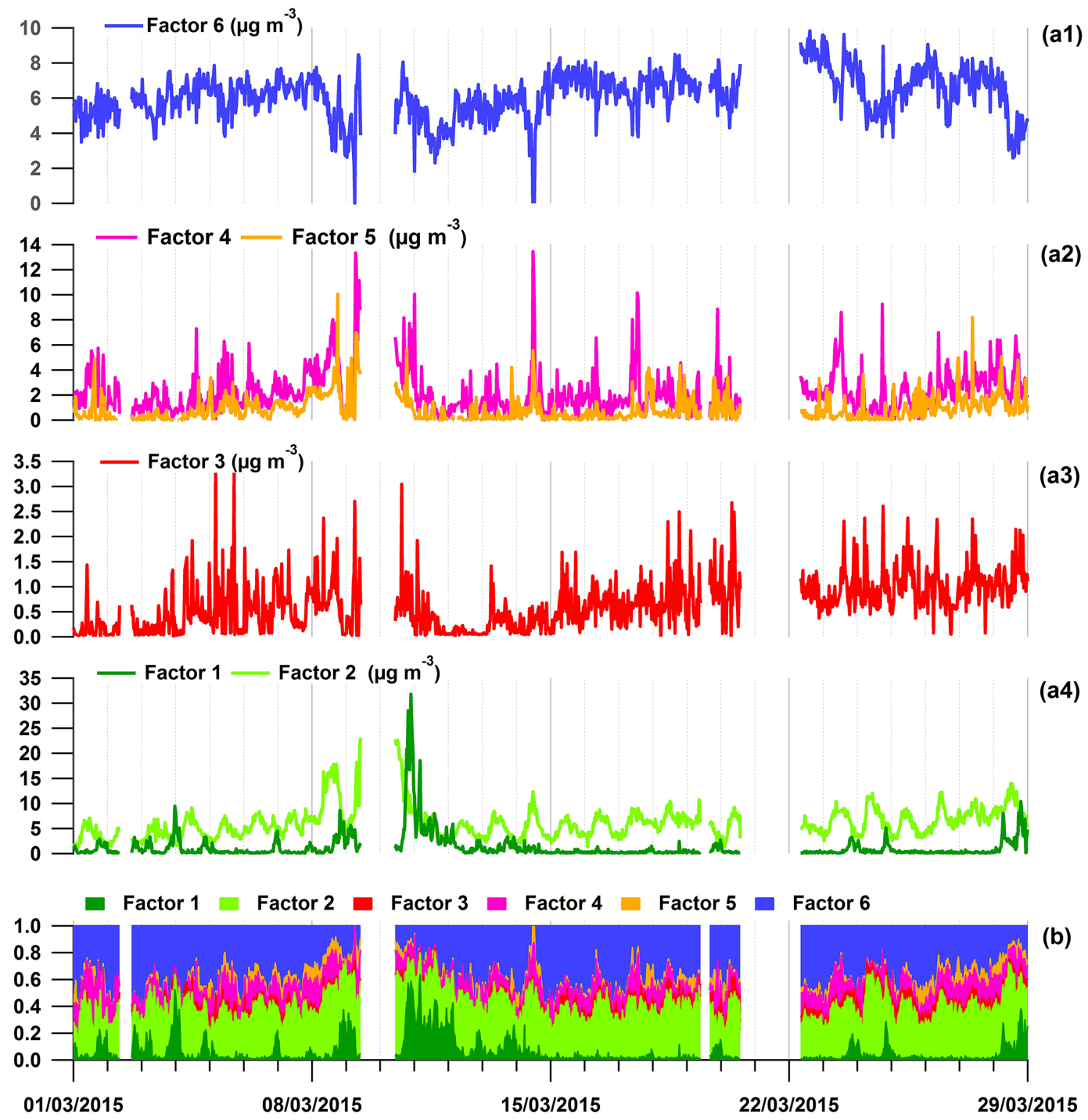

Figure 8. Time series of VOC factor contributions $\left(\mathbf{a}-\mu \mathrm{g} \mathrm{m}^{-3}\right)$ and accumulated relative VOC contributions (b). Factor $1-$ biogenic source 1; factor 2 - biogenic source 2; factor 3 - short-lived combustion source; factor 4 - evaporative sources; factor 5 - industrial and evaporative sources; factor 6 - regional background.

a clear variability except for a slight increase in midmorning (Fig. 10), the time series shows a scattered variability (Fig. 8). CPF analysis of factor 3 does not clearly highlight a wind sector except maybe southeast winds, supporting a local origin of this combustion source. The temporal variation was less pronounced on weekends than weekdays (average contribution of 0.5 and $0.7 \mu \mathrm{g} \mathrm{m}^{-3}$, respectively) consistent with human activities. This factor was hence attributed to "a short-lived combustion source" (Leuchner et al., 2015; Michoud et al., 2017).

The average contribution of factor 4 is approximately estimated at $2.7 \mu \mathrm{g} \mathrm{m}^{-3}(13 \%)$ during the studied period. This factor is composed of primary anthropogenic VOCs with medium to long lifetimes. The profile of this anthropogenic source exhibits a high contribution from alkanes, mostly $i$ -
In-butanes with lifetimes ranging from 5 to 6 days and with more than $60 \%$ of their variabilities explained by this factor, but also ethane ( $13 \%$ explained -47 days), propane ( $22 \%-$ 11 days) and $n$-pentane ( $18 \%-3$ days). The $\mathrm{C}_{4}-\mathrm{C}_{5}$ alkanes are found in the gasoline composition and evaporation source (Salameh et al., 2014, 2016). Ethane and propane can also appear as a significant profile signature of natural gas use. The total contribution of these compounds to factor 4 is up to $68 \%$. The diurnal variation in this source exhibits higher contributions during the day with peaks during the period 10:00-15:00 LT corresponding to the typical circulation of vehicles on the hill where the station is located. The CPF plot exhibits high contributions originating from the north, northeast and east wind sectors, e.g., the direction of the Nicosia region with its road traffic. Note that more than $85 \%$ 

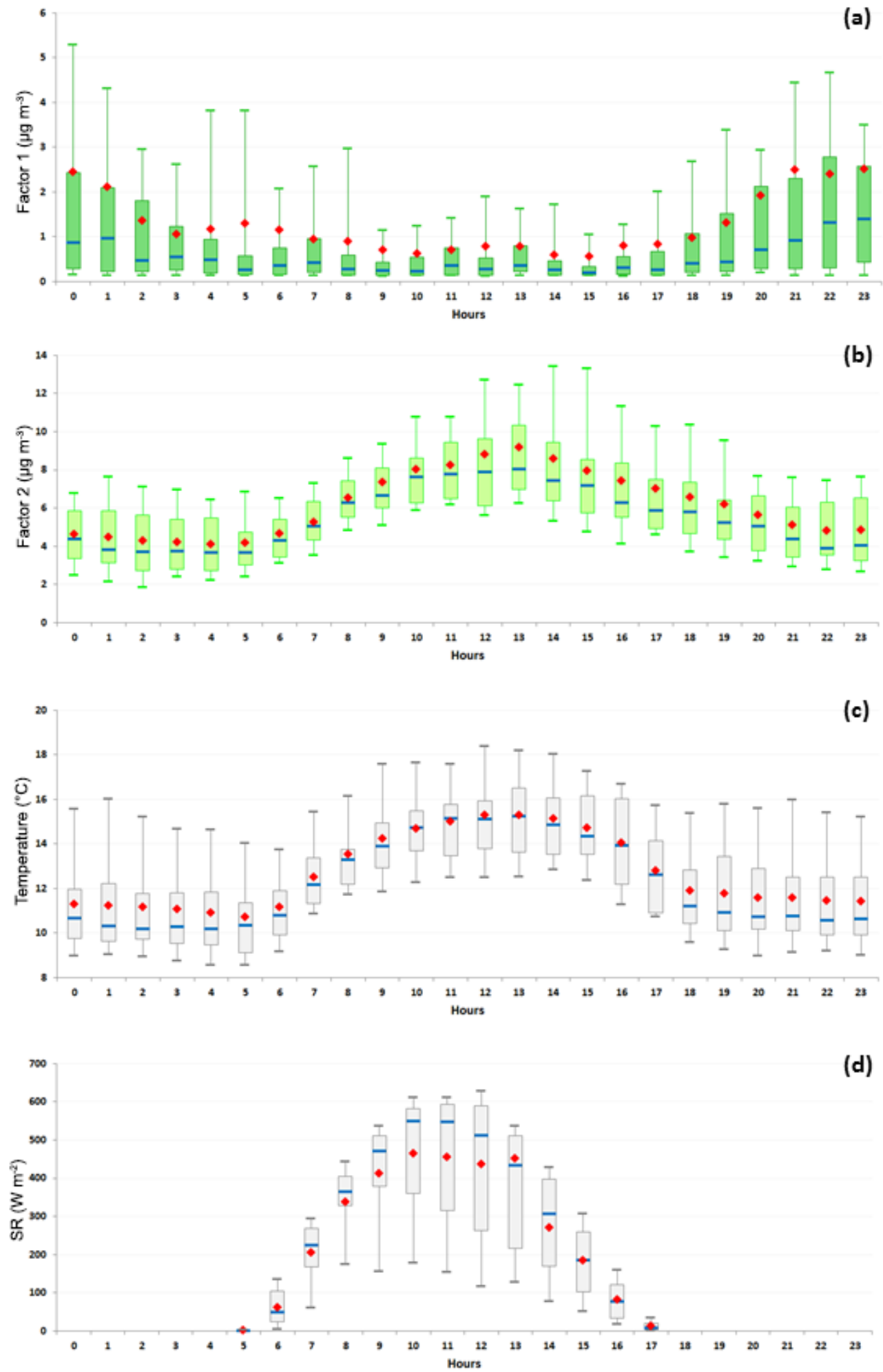

Figure 9. Diel variation in the VOC factor contribution (a, b), temperature and solar radiation (c, d) represented by hourly box plots. Blue solid line represents the median value, the red marker represents the mean value and the box shows the interquartile range. The bottom and the top of the box depict the first and the third quartiles (i.e., Q1 and Q3). The ends of the whiskers correspond to the first and the ninth deciles (i.e., D1 and D9). Time is given as local time. 

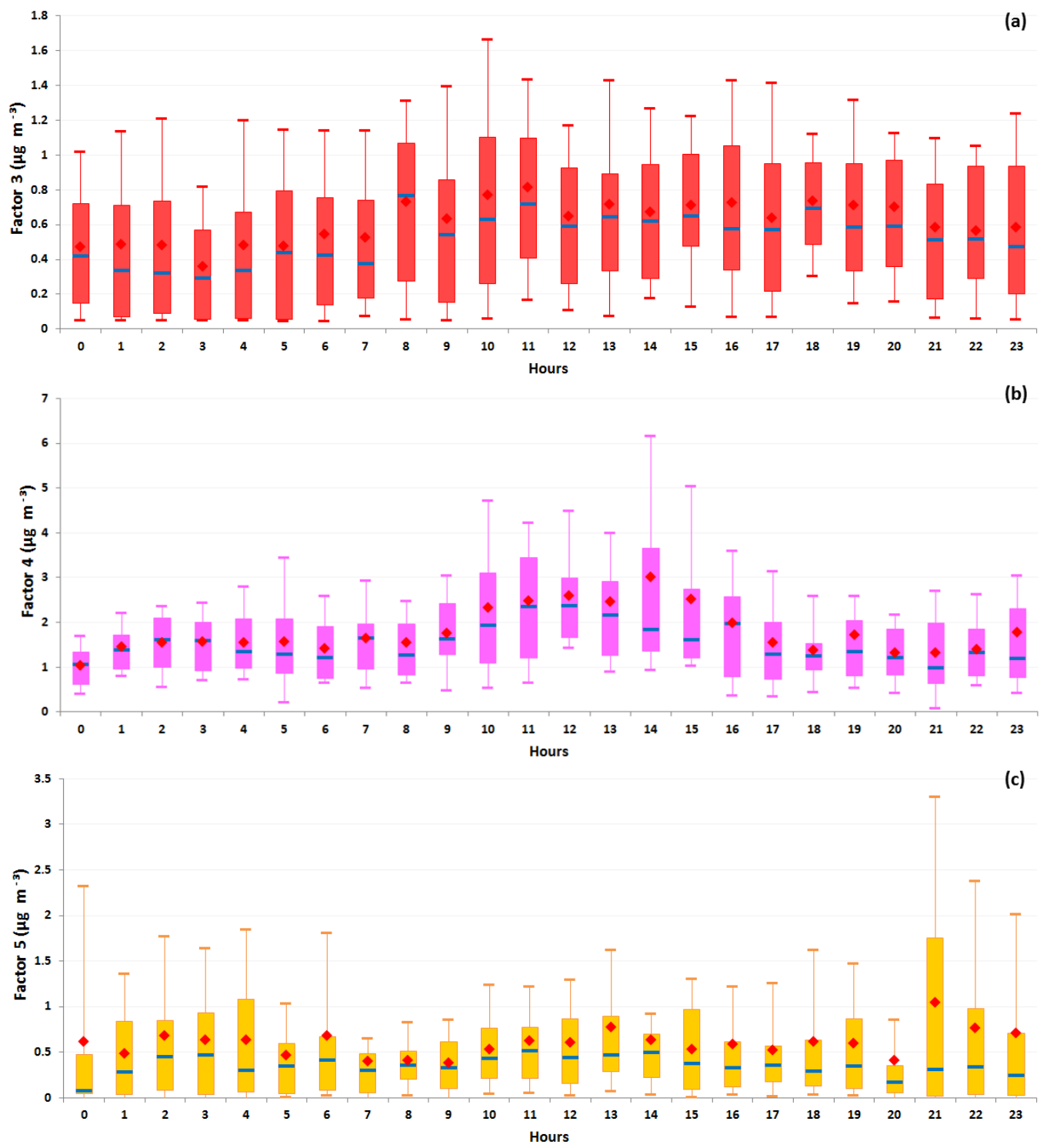

Figure 10. Diel variation in the factor contributions $(\mathbf{a}-\mathbf{c})$ represented by hourly box plots. Diurnal profiles do not include contributions obtained when the site was under the influence of air masses categorized as belonging to cluster 7. Blue solid line represents the median contribution, the red marker represents the mean contribution and the box shows the interquartile range. The bottom and the top of the box depict the first and the third quartiles (i.e., Q1 and Q3). The ends of the whiskers correspond to the first and the ninth deciles (i.e., D1 and D9). Time is given as local time.

of Cyprus passenger cars consume petrol (Eurostat, census 2013). Consequently, factor 4 can be viewed as "evaporation sources" including gasoline evaporation and with local origins. Regional origins were also not discarded as demonstrated in CF results (Fig. S6): potential emission areas could be the southwest and southeast coasts of Turkey.

Factor 5 only represents up to $5 \%$ of the sum of measured VOCs with episodic contributions of up to $27 \%$ (Fig. S7). Factor 5 is composed of primary anthropogenic species with medium lifetimes (total contribution of these compounds for factor 5 of $45 \%$ ) such as $i$-pentane $(92 \%$ explained by fac- tor 5), $n$-pentane (69\%) and 2-methylpentane (27\%), with lifetimes ranging from 2 to 3 days and typically emitted by gasoline evaporation as factor 4 . Despite their similar variations, the PMF model assigned $i$ - and $n$-butanes and $i$ and $n$-pentanes to two different factors. As $i$ - and $n$-butanes concentrations have shown higher background levels than $i$ and $n$-pentanes consistent with their respective lifetime, this may partly explain the distinction between these two factors. Significant contributions (34\% in total) for aromatic compounds, benzene ( $6 \%$ explained by factor 5$)$, toluene $(48 \%)$ and $\mathrm{m} 107(12 \%)$, some OVOCs, methanol (4\%), and 

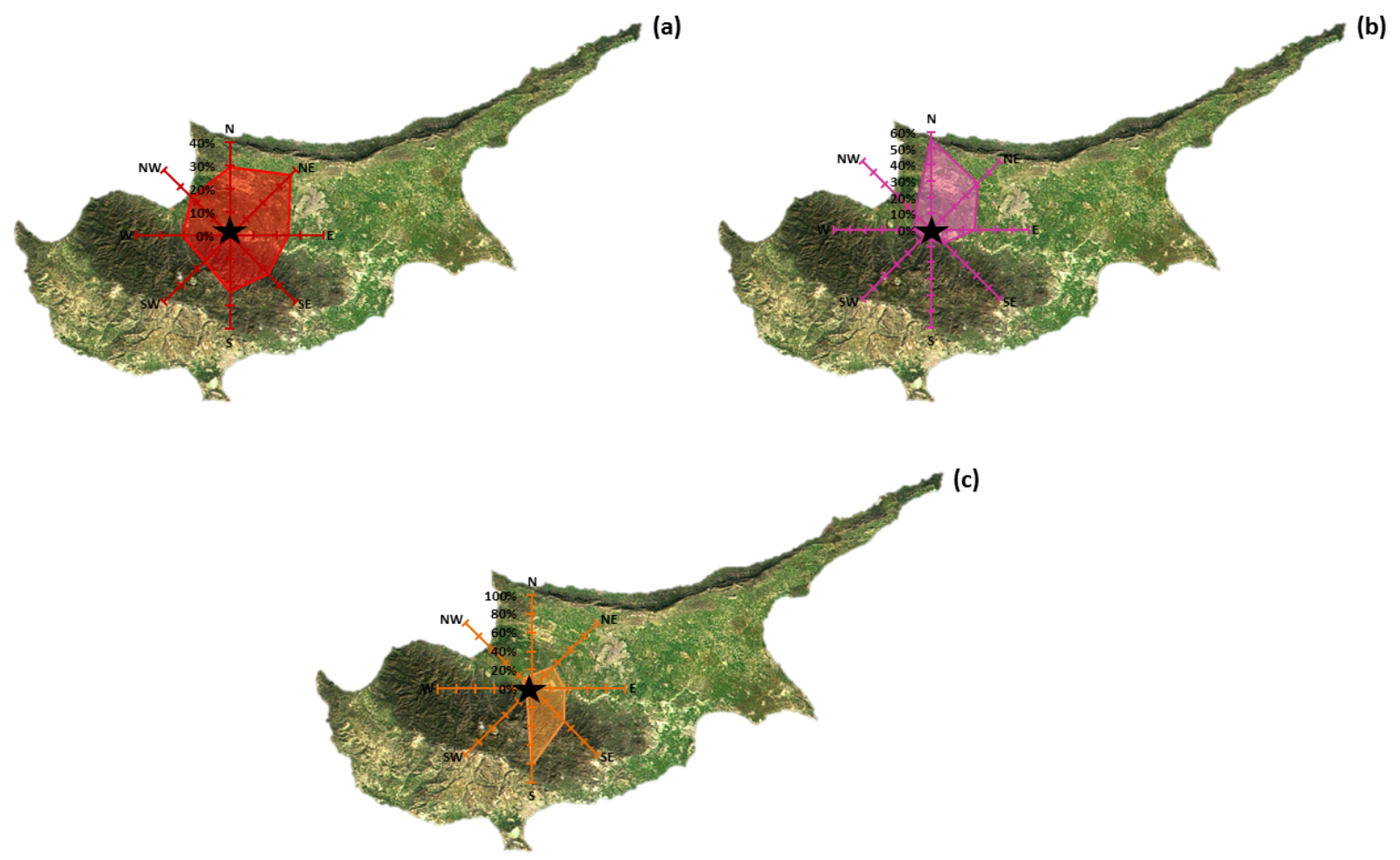

Figure 11. Rose of the CPF for VOC factors 3, 4, 5 (a-c, respectively). CPF results do not include contributions obtained when the site was under the influence of air masses categorized as belonging to cluster 7.

acetone $(2 \%)$, are also observed. Furthermore, factor 5 was mainly influenced by another geographical location compared to factor 4 . The time series of factor 5 presented in Fig. 8 has shown that this factor was primarily episodic with a high contribution which seemed to be originating from the south and southeast wind sectors as suggested by the CPF plotted in Fig. 11. Regarding Cyprus emissions inventories (Tsilingiridis et al., 2010), these directions may correspond to the Larnaca region and different industrial implementations: several small industry areas are located in these directions but also industrial plants, e.g., three power plants (using heavy fuel and diesel for their boilers - DLI, 2016) and two cement plants (only one was in operation in 2015 - DLI, 2016) located near the south and southeast coasts of Cyprus. A refinery was also referenced in Tsilingiridis et al. (2010), but it was shut down in 2004 and then converted into an oil storage terminal (all fuels consumed in the island have been imported since then - DLI, 2016). The contribution of long-range transport cannot be discarded either. The diurnal pattern of this factor (Fig. 10) has shown high contributions during the nighttime, appearing to be relatively intense compared to other anthropogenic behaviors and probably driven by dynamical processes. Furthermore, diurnal profiles of factor 5 presented in Fig. S8 displayed a distinction between contributions under south-southeast wind directions and others. In fact, the station was only under the influence of wind coming from the south and the southeast directions from
18:00 to 08:00 LT, explaining this nocturnal influence transported to the site by local wind circulation. The diurnal profile excluding high industrial contributions has shown a diurnal variability (07:00-18:00 LT) in agreement with factor 4 $(r=0.64)$. This finding suggests that the diurnal contributions of factor 5 could be associated with evaporation sources including gasoline evaporation with local origins potentially associated with the Nicosia region (Fig. 11) and/or regional origins, (south of Turkey - Fig. S6). Furthermore Salameh et al., 2016 found a "gasoline evaporation" factor, obtained from measurements realized in winter 2012 in the eastern suburb of Beirut, with a profile resembling factor 5 and high contributions corresponding to a particular wind direction, which in turn corresponded to the location of a fuel storage facility. Therefore, factor 5 may include evaporative sources, and it was labeled "industrial and evaporation sources" for that reason.

\subsubsection{Regional background (factor 6)}

With an average contribution estimated to be $6.1 \mu \mathrm{g} \mathrm{m}^{-3}$, factor 6 is the second main VOC source observed during March 2015 at CAO explaining 36\% of TVOC. Factor 6 is mainly composed of long-lived primary anthropogenic VOCs, such as ethane (70\% explained by this factor), propane $(68 \%)$, acetylene $(74 \%)$, and benzene $(76 \%)$ with lifetimes ranging from 11 to 47 days and typically emitted by 
natural gas use and combustion processes. The total contribution of these compounds to factor 6 was up to $70 \%$, with more than $57 \%$ only attributed to ethane and propane. Other anthropogenic NMHCs with shorter lifetimes compose this factor, such as toluene (33\%), 2-methylpentane (33\%) and $\mathrm{C}_{8}$ aromatic compounds ( $27 \%$ ), although with a low contribution to factor 6 (below $3 \%$ ). Additionally, the profile of factor 6 explains to a large extent some OVOCs such as acetone $(38 \%)$ and MEK (30\%). These species represent $19 \%$ of the total load for this factor. Various sources, either primary or secondary (Singh et al., 2004; Yáñez-Serrano et al., 2016), can be associated with these oxygenated compounds characterized by long atmospheric lifetimes but their association with long-lived anthropogenic species suggested primary/secondary anthropogenic contributions. Indeed, several studies performed in urban or in rural areas (de Gouw et al., 2005; Goldstein and Schade, 2000; Legreid et al., 2007) have attributed about half of these oxygenated compound concentrations to regional background pollution. Hence, the high abundance of long-lived species, in combination with the lack of shorter-lived compounds, suggests here aged air masses transported towards the sampling site. Furthermore, factor 6 exhibits variability similar to CO (see Fig. 12), supporting the identification of this factor as corresponding to long-lived compounds mainly of anthropogenic origin. The diurnal pattern of this factor (Fig. 13) is mainly based on the diurnal variation in ethane which is characterized by a nighttime maximum and a midday minimum. The diurnal profile of factor 6 displays higher levels during the night under a shallow inversion layer followed by a concentration decrease, which could be attributed to the increase in the planet boundary layer (PBL) and the vertical mixing. The potential source areas associated with this factor (Fig. 14) can be pinpointed to the south coast of Turkey (Antalya, Mersin and Gaziantep provinces - northwest Asian air masses). An additional minor continental contribution seems to be associated with the Peloponnese region (Greece - European air masses). As a conclusion, factor 6 can be interpreted as a regional contribution of various remote sources of the Mediterranean region, hence showing the continental regional background (Hellén et al., 2003; Leuchner et al., 2015; Sauvage et al., 2009). These sources were transported towards the receptor site by aged air masses which had not recently been in contact with additional anthropogenic sources. Within the time of transport of emissions from distant sources, atmospheric oxidation removes the reactive species and the remaining fraction contains mostly the less reactive species, such as ethane, propane and some OVOCs. Finally, it is reported here as "regional background".

\section{Discussions}

\subsection{Comparisons with VOC measurements conducted in the Mediterranean}

\subsubsection{Comparisons with VOC measurements conducted at a different background site of Cyprus}

To the best of our knowledge, only one study has reported VOC measurements performed at a background site of Cyprus with a similar typology to the CAO station. Indeed, during the CYPHEX summertime campaign (Cyprus Photochemical Experiment 2014), VOC measurements were conducted mostly using a PTR-MS at a rural site (Ínia) located in the southwest of the Troodos mountain range. Derstroff et al. (2016) have examined the temporal variation in VOCs observed during this campaign and investigated the impact of air masses originating from eastern and western Europe and of the marine boundary layer on VOCs, especially OVOCs.

A comparison between the two studies shows that each sampling site exhibited very low mixing ratios of primary anthropogenic compounds as expected from their remoteness from local pollution sources. For biogenic compounds, Derstroff et al. (2016) identified that the sparse local vegetation close to their site produced only modest concentrations of biogenic compounds (average concentration of $\sim 0.26$ and $\sim 0.33 \mu \mathrm{g} \mathrm{m}^{-3}$ for isoprene and the sum of monoterpenes, respectively) with both daily maxima and a solarradiation-dependent pattern. In our study, isoprene has shown also daily variability and low concentrations $\left(0.13 \mu \mathrm{g} \mathrm{m}^{-3}\right)$ but consistent with the respective period of each campaign (CAO: winter/spring; Ínia: summer), leading to a different range of temperatures (average diel variations in the temperature between $11-15$ and $22-25^{\circ} \mathrm{C}$ for $\mathrm{CAO}$ and Ínia, respectively). However, despite the lower temperature observed during our campaign, monoterpenes have shown higher levels $\left(1.34 \mu \mathrm{g} \mathrm{m}^{-3}\right)$ at $\mathrm{CAO}$, with nighttime maxima and potential production by oak and pine forests.

OVOCs observed during the CYPHEX campaign have shown high values (average concentration of $\sim 4.08$ and $\sim 5.64 \mu \mathrm{g} \mathrm{m}^{-3}$ for methanol and acetone, respectively) and revealed little diel variation, indicating that local emission or production was minor in comparison to long-range transport. In this study, we found more pronounced OVOC diel variations (not shown in this article but similar to biogenic source 2 diel variation), a comparable average concentration of methanol $\left(3.84 \mu \mathrm{g} \mathrm{m}^{-3}\right)$ with mostly biogenic origins and a lower concentration of acetone $\left(2.72 \mu \mathrm{g} \mathrm{m}^{-3}\right)$ with both biogenic origins (biogenic source 2) and primary/secondary anthropogenic origins (regional background). As a result, local origins were as significant as long-range transport in our study. Consistent with our findings, Derstroff et al. (2016) found higher OVOC mixing ratios when air masses came from eastern Europe and lower ones when they arrived from western areas. 
Back-trajectory clusters
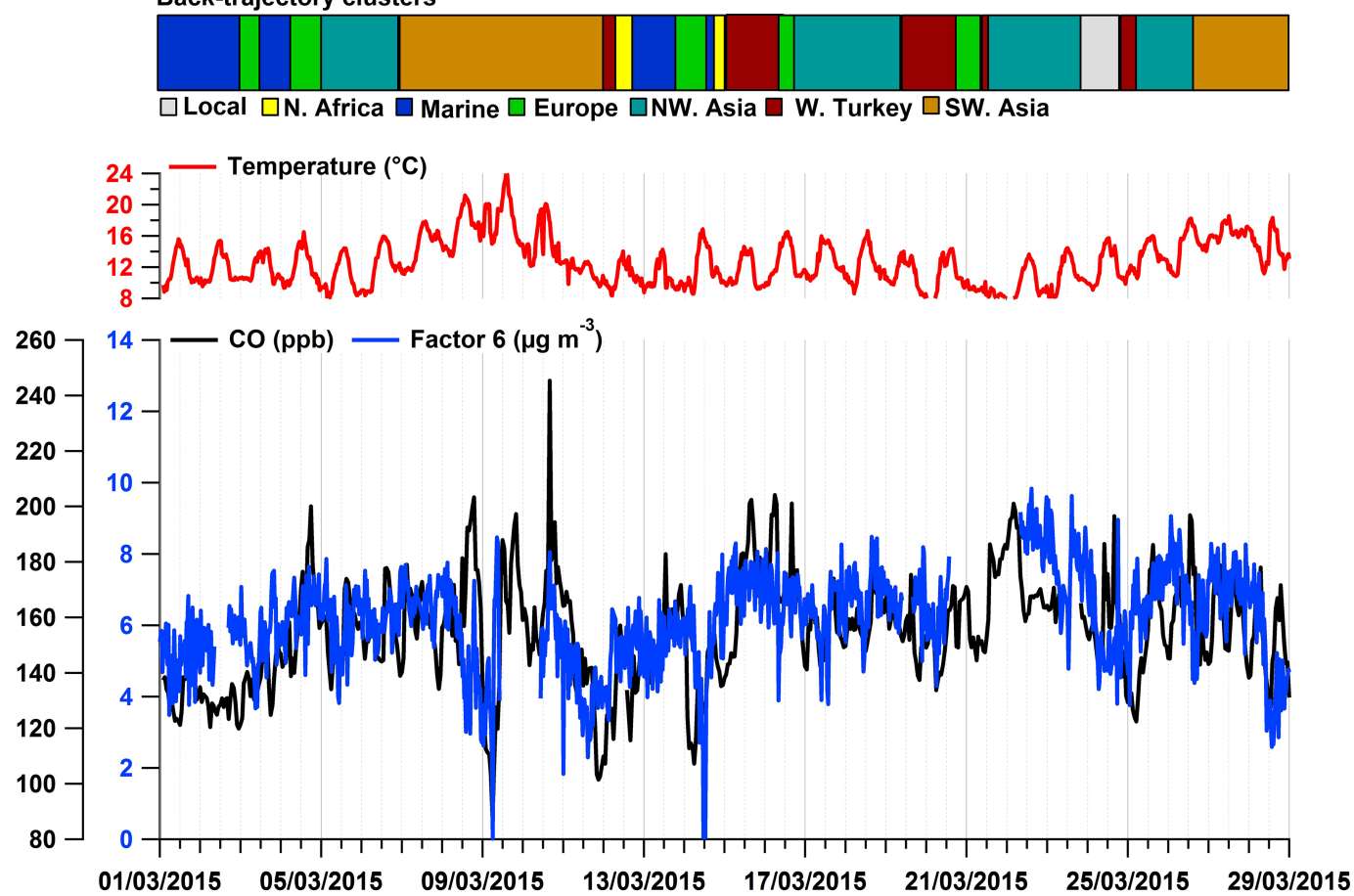

Figure 12. Time series of the VOC factor 6 contribution (blue line) and CO (dark line).

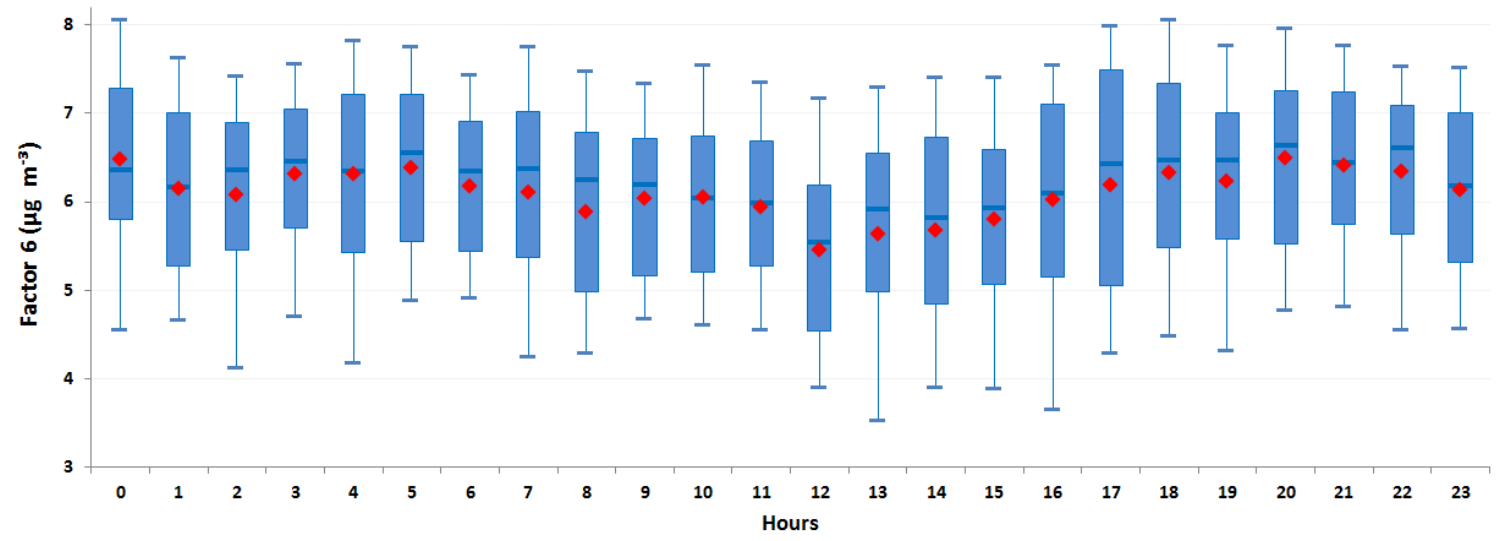

Figure 13. Diel variation in the VOC factor 6 contributions represented by hourly box plots. Blue solid line represents the median contribution, the red marker represents the mean contribution and the box shows the interquartile range. The bottom and the top of the box depict the first and the third quartiles (i.e., Q1 and Q3). The ends of the whiskers correspond to the first and the ninth deciles (i.e., D1 and D9). Time is given as local time.

\subsubsection{Comparison with another PMF study performed at a remote site of the Mediterranean region}

Michoud et al. (2017) have reported gas and aerosol measurements conducted at a French remote site of the Western Mediterranean region (Cape Corsica) during the ChArMEx SOP2 field campaign (summer 2013). They performed a PMF analysis on a gas database made of 42 VOCs, including primary VOCs with anthropogenic and biogenic origins, and OVOCs and therefore offer a unique opportunity to provide a characterization of VOCs for the entire Mediterranean. Note that the same species had different lifetimes at each site since we considered a lower $\mathrm{OH}$ concentration, leading to a higher lifetime, but this is consistent with respective measurement periods (CAO: winter/spring; Cape Corsica: summer).

At both sampling sites, primary anthropogenic PMF factors were separated according to the lifetime of the com- 

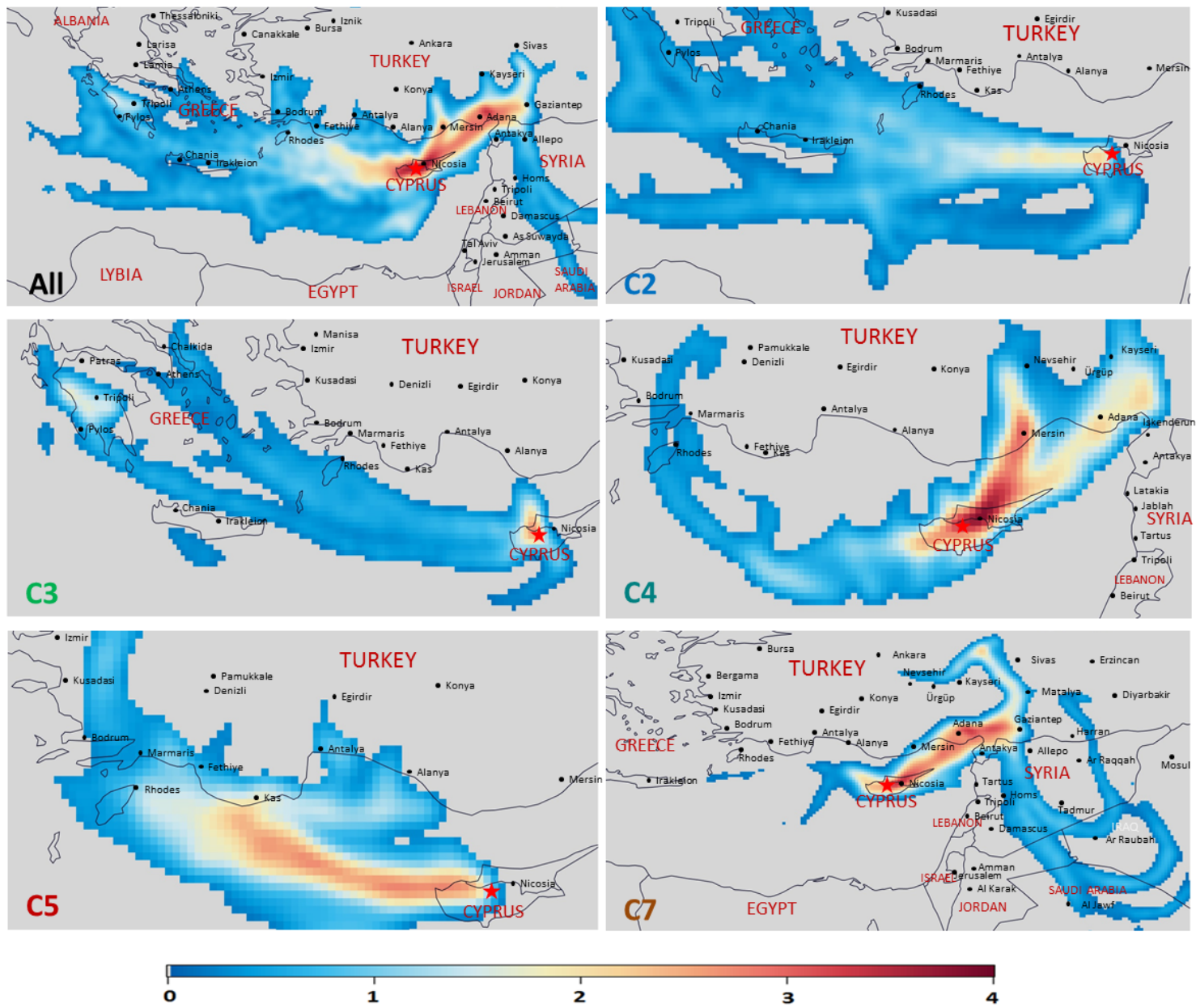

Figure 14. Potential source areas contributing to the VOC factor 6 in the function of air mass origins. Contributions are in units of $\mu \mathrm{g} \mathrm{m}^{-3}$ All - without distinction of air mass origins; C2 - marine air masses; C3 - Europe; C4 - northwest Asia; C5 - west of Turkey; C7 - southwest Asia. The low numbers of samples associated with clusters 0 and 1 (local and N. Africa, respectively - Fig. 2) does not allow us to apply $\mathrm{CPF}$ analysis only considering these air mass origin.

pounds which composed them, suggesting a homogeneity phenomenon in the entire basin. Similar to our regional background factor, their "long-lived anthropogenic" factor was mainly composed of long-lived primary anthropogenic VOCs but also of oxygenated compounds (e.g., methanol and acetone), covarying with $\mathrm{CO}$ and showing potential distant sources originated from Europe (the north of Italy and the southeast of France) and Africa (the northeast of Tunisia). In this study, distant anthropogenic sources (regional background factor) have shown potential origins mainly associated with the Eastern Mediterranean region, and they represented a higher share of the sum of measured VOCs (CAO: $36 \%$; Cape Corsica: 16-17\%) inducing a lower share of the short-lived anthropogenic factor (CAO: $43 \%$; Cape Corsica: $21-23 \%)$.

Different patterns were noticed concerning biogenic sources identified at these two Mediterranean receptor sites. We found a biogenic factor with a clear diurnal cycle cor- related with temperature (biogenic source 2) but also a second biogenic source with nighttime maxima (biogenic source 1); hence, this further distinguished biogenic sources contributing to isoprene and monoterpenes concentrations contrary to Michoud et al. (2017). This difference to Michoud et al. (2017) may be linked to the type of Mediterranean vegetation characterizing each measurement site, or different processes may also have occurred. Biogenic sources represented significant contributors to the VOC concentrations observed at these sampling sites (CAO: $36 \%$; Cape Corsica: $20 \%$ ).

Finally, oxygenated compounds were incorporated in these two studies, but they were apportioned differently. Our PMF analysis did not allow us to clearly separate primary sources from secondary sources contrary to Michoud et al. (2017), but we obtained a better distinction between anthropogenic and biogenic origins of measured OVOCs. Hence, OVOCs were mainly explained by biogenic sources in this study (64\%). 


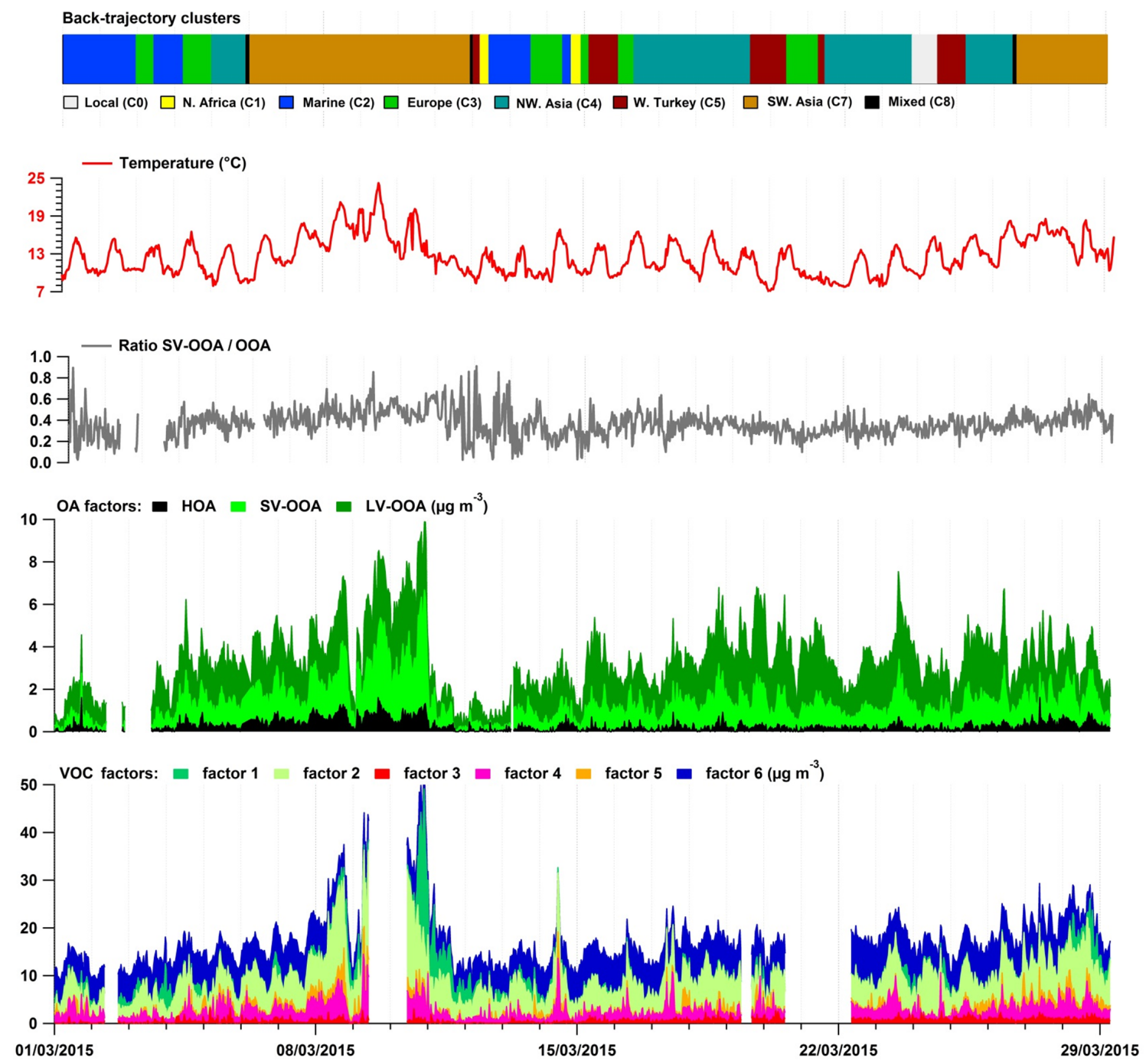

Figure 15. Accumulated time series of OA and VOC factor contribution; time series of temperature and air mass origin (C: cluster). VOC factors: factor 1 - biogenic source 1; factor 2 - biogenic source 2; factor 3 - short-lived combustion source; factor 4 - evaporative sources; factor 5 - industrial and evaporative sources; factor 6 - regional background. OA factors: HOA - hydrogen-like OA; SV-OOA - semi-volatile oxygen-like OA; LV-OOA - low-volatility oxygen-like OA.

\subsection{Exploring the potential of VOCs in secondary organic aerosol formation}

\subsubsection{Source apportionment of organic aerosols}

Foremost, we only considered the organic fraction of NR$\mathrm{PM}_{1}$ in this study. Following the same method as Michoud et al. (2017), organic aerosol (OA) concentration was apportioned to three factors using a constrained PMF analysis: HOA (hydrogen-like OA), SV-OOA (semi-volatile oxygenlike OA) and LV-OOA (low-volatility oxygen-like OA). During our study, average mass contributions were $0.30,1.14$ and $1.89 \mu \mathrm{g} \mathrm{m}^{-3}$, for the three determined factors HOA, SVOOA, and LV-OOA, respectively, and for a total OA concentration of $3.33 \mu \mathrm{g} \mathrm{m}^{-3}$. Mass spectra profiles are presented in Fig. S9. Very low contributions of HOA were observed during the whole campaign, illustrating the weak influence of local anthropogenic sources of OA at the site, while secondary OA represented about $91 \%$ of OA and was mainly composed of aged LV-OOA (63\% of OOA).

Figure 15 reports the time series of accumulated OA factors. From 4 to 10 March, OA concentrations increased progressively up to $10 \mathrm{\mu g} \mathrm{m}^{-3}$ together with an increase in SVOOA contributions to OA levels (up to $66 \%$ ). The daily average SV-OOA concentration observed on 10 March was three times higher compared to 4 March. Similar patterns were also noticed for HOA and LV-OOA but were less pronounced (2 times higher). This period corresponded to a progressive increase in daily temperature (diel maximum temperatures increasing from 16 to $24^{\circ} \mathrm{C}$ ), leading to favorable conditions 
for VOC emission/formation but also to air masses coming from northwest and southwest Asia, especially from the south of Turkey. OA concentrations were drastically reduced on 11 March due to precipitation and change in air mass origin. Other increases in OA concentrations were noticed, from 14 to 21 and 22 to 29 March, consistent again with the temperature trend but with less pronounced variability than in the first period. From 26 to 29 March, the SV-OOA contribution to OA concentrations increased significantly when the station was under continental influence (cluster 7: southwest Asia) whereas the LV-OOA contribution was lower.

\subsubsection{Relationship between VOCs and OA}

Figure 15 aims at drawing a parallel between OA and VOCs to highlight the link between the two phases. Figure 16 shows accumulated contributions of OA and VOC factors as a function of air mass origin. Note that due to their local origins, biogenic VOC factor contributions did not depend on longrange transport and higher contributions were only observed when the station received air masses originating from local and southwest Asia (clusters 0 and 7, respectively - Fig. 2) due to favorable days with the highest daily temperatures observed during March 2015. The continental influence on anthropogenic factors when the site received air masses coming from the Eastern Mediterranean region (i.e., northwest Asia and southwest Asia) was higher than when it received air masses coming from the western region (i.e., Europe) as expected from the distance which separates the source region and the measuring site. Indeed, potential emission areas attributed to the Western Mediterranean region influence of the site (as depicted by CF results plotted in Fig. 14) are far from the sampling station $(600-950 \mathrm{~km})$, while the south Turkish coast is much closer to the site $(100-250 \mathrm{~km})$. As a consequence, the shorter distance of potential Eastern Mediterranean emission areas could lead to an injection of fresher anthropogenic sources in air masses observed at CAO. Additionally, a higher continental influence was noticed on anthropogenic factors when the site received air masses coming from the west of Asia than the west of Turkey. A potential emission area associated with air masses originating from the west of Turkey was the southwest coast of Turkey (Fig. 14), corresponding to less densely populated areas compared to the southeast coast of Turkey (Sect. 3.5.2). Note that additional, more distant emission areas of the west of Turkey, such as the Istanbul region with expected high anthropogenic emissions, were not observed by CF plots, which could explain why CAO was not influenced by important anthropogenic emission areas when air masses originated from the west of Turkey.

We first investigated the average OA contributions according to air mass origin, and we supported our findings based on the variability in VOC factors. The lowest OA concentration was observed when the station was under the influence of marine air masses (cluster 2 - Fig. 2). Likewise, total VOC concentration was also low during this period mostly because of a low contribution of the regional background VOC factor, which may be linked to dilution and removal processes and the fact that marine air masses have not recently been in contact with anthropogenic sources. The average OA contributions were twice as high when the station was under continental influence (i.e., Europe and Asia) compared to the concentration under marine influence. This is again consistent with the increasing trend of the VOC regional background factor during this period. Furthermore, we noticed a higher continental influence on OA total contribution when air masses originated from the Eastern Mediterranean (clusters 4, 5 and 7 associated with air masses originating from west Asia - Fig. 2) compared to the Western Mediterranean (cluster 3 associated with air masses originating from Europe - Fig. 2). The stronger continental influence of air masses originating from the Eastern Mediterranean region has also led to a higher contribution of VOC anthropogenic factors (Fig. 16) and higher organic aerosol emissions and formation.

We also investigated the variability in each OA factor individually using their diel variations (Fig. S10) and their variation according to air mass origin (Fig. 16). HOA diel variation has shown a slight increase during the day and then a second wave in the late afternoon. HOA was also correlated with VOC anthropogenic factors ( $r=0.39$ and 0.40 for VOC factors 4 and 5, respectively, both with a $p$ value $<1 \times 10^{-5}$ ). Although HOA concentrations are very low, these results suggest a local origin (potentially the Nicosia and Larnaca regions) but also the influence of long-range transport (particularly when the station received air masses originating from the Eastern Mediterranean region - Figs. 15 and 16).

It is interesting to note the weakly positive but significant correlation found between freshly (locally) produced SVOOA and VOC biogenic sources $(r=0.52$ and 0.53 for VOC factors 1 and 2, respectively, both with a $p$ value $<1 \times 10^{-5}$ ). Indeed, the diurnal variation in SV-OOA was characterized by a morning minimum followed by a daily maximum with an increase from 08:00 to 12:00 LT consistent with VOC biogenic factor 2 variability (Fig. S10). Using the time series of a selected day of the campaign (26 March - Fig. 17b1), a possible link between SV-OOA and VOC biogenic source 2 could be established based on their common daily variations. Moreover, during the nighttime, SV-OOA variability exhibited a second maximum (Fig. S10) that could be linked with the biogenic influence from factor 1 and also with dynamical processes (higher contribution during the night under a shallow inversion layer). On 10 March (Fig. 17b2), the increase in SV-OOA at 17:00 LT was in phase with an increase in the VOC biogenic source 1. In addition to these biogenic contributions, anthropogenic VOC precursors may also contribute to SV-OOA formation. We found a good Pearson coefficient between SV-OOA and VOC anthropogenic factor contributions $(r=0.42$ and 0.44 for VOC factors 4 and 5 , respectively, both with a $p$ value $<1 \times 10^{-5}$ ) as il- 

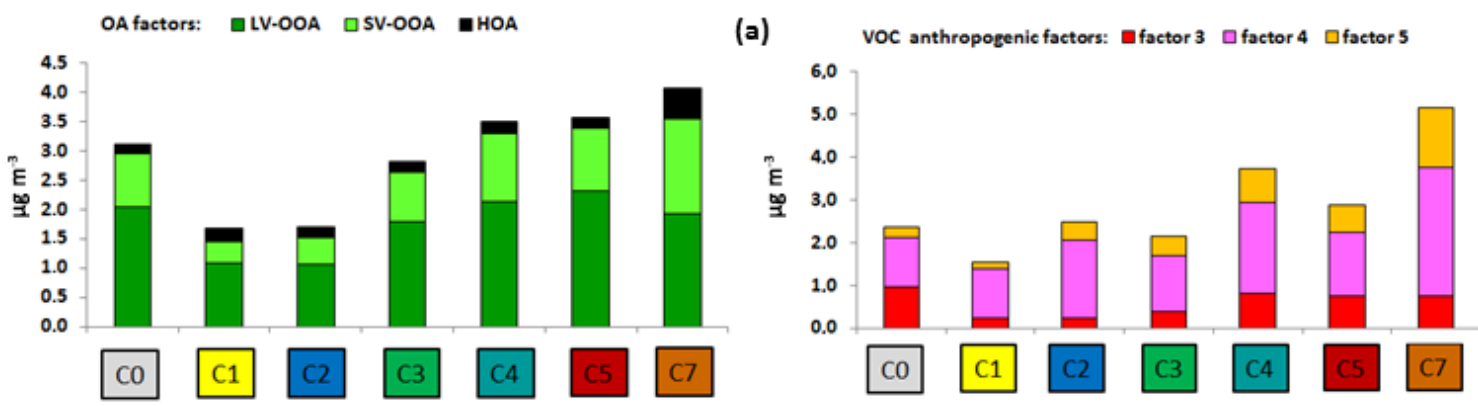

(b1)

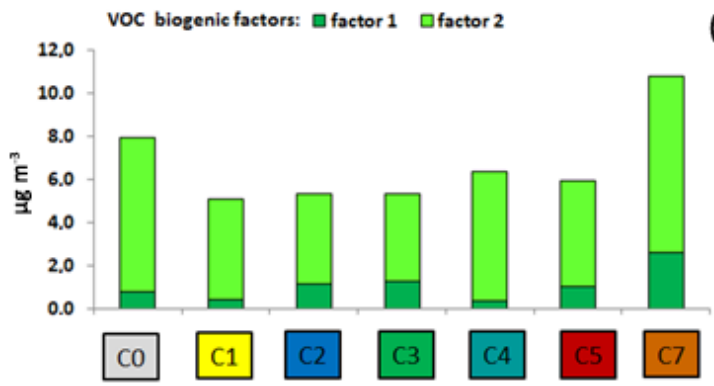

(b2)

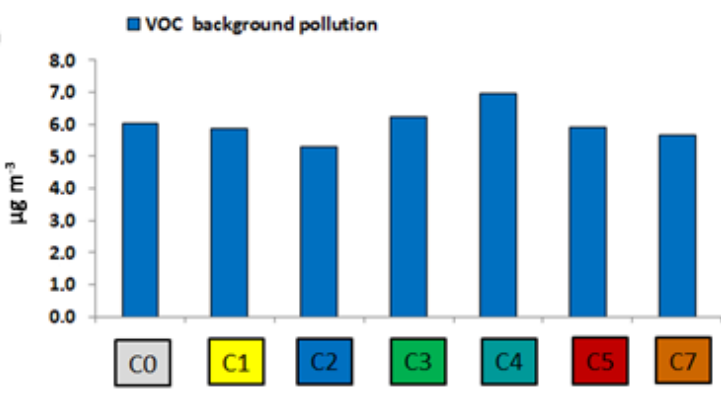

(b3)

Figure 16. Accumulated average contributions of the OA and VOC factors (a and $\mathbf{b}$, respectively) as a function of air mass origins. Classification of air masses: C0 - local; C1 - N. Africa; C2 - marine; C3 - Europe; C4 - northwest. Asia; C5 - the west of Turkey and C7 southwest Asia. VOC factors: factor 1 - biogenic source 1; factor 2 - biogenic source 2; factor 3 - short-lived combustion source; factor 4 - evaporative sources; factor 5 - industrial and evaporative sources; factor 6 - regional background. OA factors: HOA - hydrogen-like OA; SV-OOA - semi-volatile oxygen-like OA; LV-OOA - low-volatility oxygen-like OA.

lustrated on 28 March (Fig. 17b3). Higher SV-OOA contributions were noticed when the station was under continental air masses than under marine air masses (SV-OOA from continental air masses was 2 to 4 times higher than from marine air masses), consistent with the respective variability in VOC anthropogenic sources. In conclusion, the diurnal variability in SV-OOA seemed to be significantly influenced by biogenic contributions but also to a lesser extent by anthropogenic contributions.

Another interesting feature is the weakly positive but significant correlation between LV-OOA and the VOC regional background factor $\left(r=0.42\right.$ with a $p$ value $<1 \times 10^{-5}$ ), which is consistent with a highly processed (aged) regional background pollution advected to the receptor site. Both parameters have shown the same variability associated with air mass origin, with higher contributions under continental influence and slightly higher contributions when the air masses originated from northwest Asia than Europe.

Finally, we have investigated more specifically VOC and OA behaviors when the station was under the influence of air masses originating from the southwest of Asia. SV-OOA contribution to OOA increased significantly under this influence (up to $86 \%$ - Fig. 15). As already discussed in Sect. 3.5.2, southwest Asian air masses corresponds to an intense anthropogenic event, potentially originating from the south coast of Turkey leading to higher primary anthropogenic VOC factor contributions (mostly VOC factors 4 and
5). When the station received southwest Asian air masses, each OA factor covaried well with the sum of contributions from factors 4 and 5, and this observation was confirmed by estimating the Pearson correlation coefficients $(0.39<$ $r<0.57$ with a $p$ value $<1 \times 10^{-5}$ ). Even though potential anthropogenic emission areas originating from northwest of Asia were similar to those of southwest Asian origin (Fig. 14), the average OA concentration was lower for the northwest Asia cluster. As stated before, the intense anthropogenic event observed when air masses came from the southwest of Asia also occurred during an intense biogenic influence period. Indeed, when the station received air masses categorized as belonging to the southwest Asia cluster, both OOA factors contributions were well correlated with VOC biogenic source 2 contributions $(r>0.46$ with a $p$ value $<1 \times 10^{-5}$ ), and only the SV-OOA factor was well correlated with VOC biogenic source 1 ( $r=0.58$ with a $p$ value $<1 \times 10^{-5}$ ). The most evident relationship between biogenic VOCs and OA was observed on 10 March (Fig. 17b2) and showed an increase in SV-OOA concentration of $4 \mu \mathrm{g} \mathrm{m}^{-3}$ in a few hours, coinciding with the maximal contribution of VOC biogenic source 1 (up to $34.8 \mu_{g^{-3}}{ }^{-3}$ ), while no significant anthropogenic contributions could be observed at that period. 

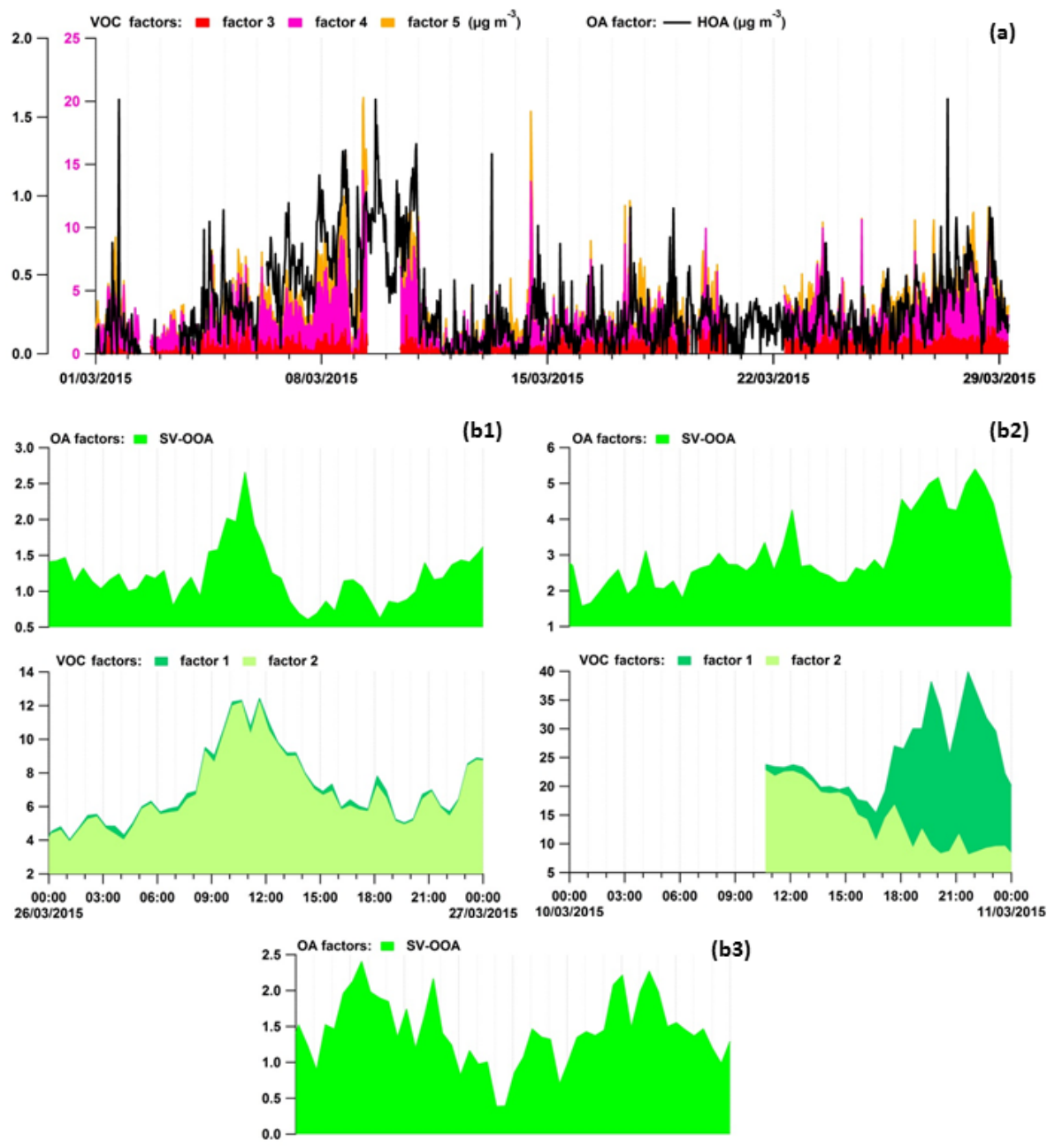

(b3)
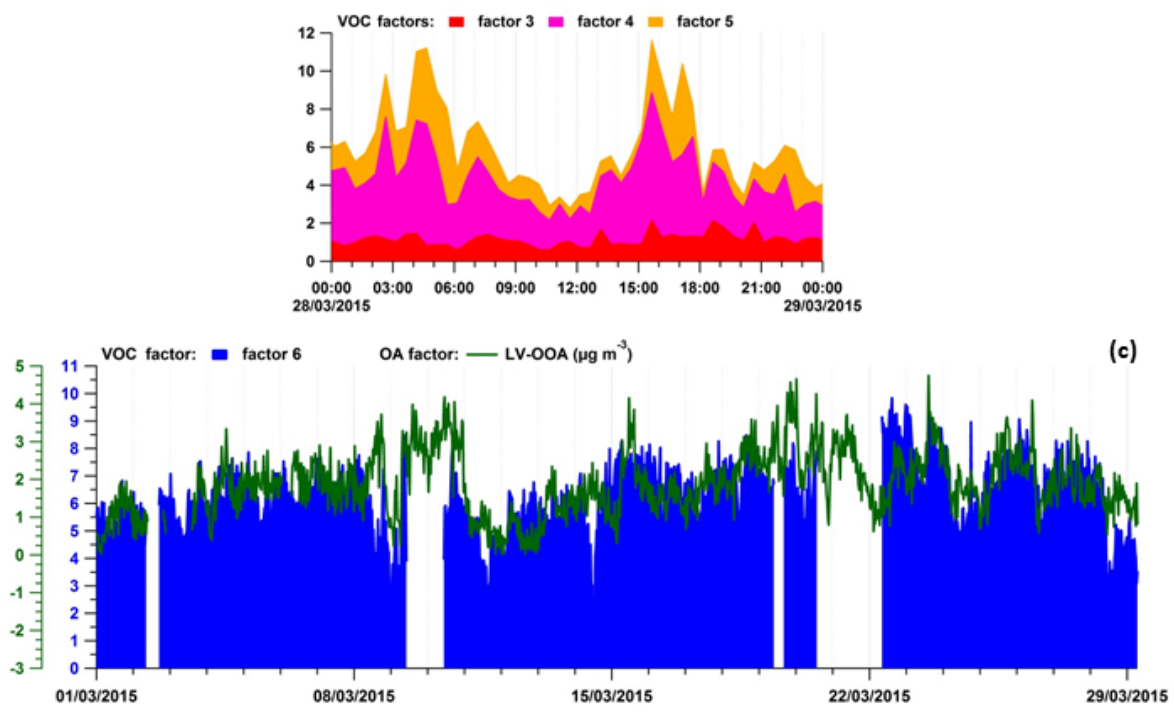

Figure 17. Time series of OA and VOC factor contributions in March 2015 (a, c) or on selected days of the intensive field campaign (b1-b3) to point out covariations and confirm average daily variations presented in Fig. S10. VOC factors: factor $1-$ biogenic source 1 ; factor $2-$ biogenic source 2; factor 3 - short-lived combustion source; factor 4 - evaporative sources; factor 5 - industrial and evaporative sources; factor 6 - regional background. OA factors: HOA - hydrogen-like OA; SV-OOA - semi-volatile oxygen-like OA; LV-OOA - low-volatility oxygen-like OA. 


\section{Conclusions}

At the crossroads of intense local natural and human-made emissions and those transported over a long distance, the Eastern Mediterranean is characterized as a sensitive region strongly affected by air pollution. This pollution is partly due to the combination of human pressure concentrated in coastal cities with more distant sources transported from three continents. This complex mixture of air pollutants will have impacts on human health, ecosystems and climate. However, observational data collected in the Eastern Mediterranean remain scarce, preventing any comprehensive assessment of the various impacts of this pollution in the region.

Within the framework of the ChArMEx and ENVI-Med CyAr programs, a 1-month intensive field campaign held in March 2015 at a background site of Cyprus has provided an unique opportunity to provide insights into the various origins and fates of VOCs in the Eastern Mediterranean region. Real-time measurements of a large number of VOCs, including alkanes, alkenes, alkyne, aromatics compounds and oxygenated VOCs, have been performed, allowing the evaluation of VOC concentration levels in ambient air, improving our understanding of their major sources in the area, and describing their variabilities and their potential origins. This period of the year typically offers contrasting conditions in terms of air masses transport (geographical origin, fast/low transport) and weather (temperature, humidity, precipitations). The remote location of the measurement site offered ideal experimental conditions to monitor clean/polluted air masses that have been transported over long distances from three continents (Europe, Africa and Asia) with the limiting influence of local anthropogenic areas. The site is also surrounded by widespread vegetation with intense local biogenic emissions, making possible the investigation of biogenic and anthropogenic interactions on air mass composition.

Low levels of primary anthropogenic VOCs with short or medium lifetimes (e.g., average concentration of 0.35 and $0.37 \mu \mathrm{g} \mathrm{m}^{-3}$ for ethylene and benzene, respectively) were measured confirming the background typology of the site. Anthropogenic VOCs exhibited higher background levels when the station was under the influence of distant sources imported by continental air masses mainly originating from west Asia. Additionally, significant levels of short-lived biogenic VOCs (up to 0.62 and $11.63 \mu \mathrm{g} \mathrm{m}^{-3}$ for isoprene and $\alpha$-pinene, respectively) were observed with a distinct diurnal pattern (daily and nighttime maximum for isoprene and $\alpha$ pinene, respectively). Elevated mixing ratios of OVOCs (e.g., up to and 12.82 and $6.46 \mu \mathrm{g} \mathrm{m}^{-3}$ for methanol and acetone) largely dominated the VOC budget and had both biogenic and anthropogenic origins in variable proportions. OVOCs can be emitted from primary sources (mainly biogenic) and can be produced by secondary sources related to the oxidation of anthropogenic and biogenic hydrocarbons, making it more difficult to assess directly their origins.
A source apportionment (PMF) analysis was conducted to better identify covariation factors of VOCs that were representative of aged or local primary emissions as well as secondary photochemical transformations occurring during the transport of air masses. The US EPA PMF v. 5.0 was applied to the dataset composed of 20 VOCs of anthropogenic and biogenic origins and a total of 1179 atmospheric data points with a $30 \mathrm{~min}$ time resolution. The best PMF solution allowed the decomposition of VOCs into six different sources; two factors attributed to biogenic sources (biogenic sources 1 and 2), three anthropogenic factors (shortlived combustion sources, evaporative sources, industrial and evaporative sources) and a last factor associated with regional background pollution. The biogenic sources and the regional background were found to be the largest contributors to the VOC concentrations observed at our background site, with a total contribution of $79 \%$. To investigate variability and origin of these factors, we based our observations on diel variabilities, $\mathrm{CPF}$ and $\mathrm{CF}$ plots. Factors attributed to biogenic sources 1 and 2, driven by pinenes and isoprene/OVOC emissions, respectively, have shown contrasting diurnal profiles (nighttime vs. daily maxima) and distinct origins (oak and pine forests vs. garrigues). Factors attributed to anthropogenic sources were characterized by compounds of various lifetimes and were influenced by several geographic locations, from local origins to distant potential emission areas such as the south coast of Turkey. The last factor was characterized by long-lived primary anthropogenic VOCs and OVOCs and was covaried, with CO supporting the identification of this factor as continental regional background.

Benefiting from real-time organic aerosol measurements performed by ACSM technique, a parallel between organic aerosol and gas phase composition was conducted during our study to better highlight the relationship between the two phases. Organic aerosol (NR-PM 1 OA) measurements were apportioned to three factors, HOA, SV-OOA and LVOOA. Very low contributions of HOA were observed during the whole campaign, illustrating the weak influence of locally emitted anthropogenic sources of OA at the site while secondary OA represented about $88 \%$ of OA, with aged OOA contributing approximately $56 \%$ of this secondary OA fraction. The diurnal variability in SV-OOA seemed to be influenced by local biogenic contributions, while LV-OOA seemed to be of regional background origin. As expected, air mass origin revealed lower contributions of OA and VOCs when clean marine air masses were advected to the station. $\mathrm{OA}$ and anthropogenic sources of VOCs were higher when the station was under continental influence coming from Eastern Mediterranean region (west Asian air masses). The highest total concentration of OA was observed when the station was under the influence of air masses coming from the southwest of Asia. The intense anthropogenic event potentially associated with the south coast of Turkey transported on the site air masses rich in semi-volatile OA (less oxidized aerosols) associated with an increase in anthropogenic VOC 
source contribution. This event also occurred during a period with intense biogenic influence leading to an increase in biogenic VOC source contribution due to favorable temperatures. The organic fraction of aerosols during this period most probably resulted in a combination of both biogenic and anthropogenic sources in variable proportions.

In the light of this study, we are writing a further paper dedicated to local biogenic emissions impacting the atmospheric composition of the site and the chemistry associated as we noticed they were significant contributors of SOA in this study. This second paper will also be a good opportunity to further compare biogenic compounds measured at CAO and Cape Corsica (levels, speciation, variability and processes). Additionally to this campaign, an annual campaign has been conducted. Twenty primary (anthropogenic/biogenic) VOCs have been measured continuously in order to study seasonal variabilities.

Data availability. All the data presented in this paper are available upon request. Please contact Stéphane Sauvage (stephane.sauvage@imt-lille-douai.fr) for further information.

\section{The Supplement related to this article is available online at https://doi.org/10.5194/acp-17-11355-2017- supplement.}

Competing interests. The authors declare that they have no conflict of interest.

Special issue statement. This article is part of the special issue "CHemistry and AeRosols Mediterranean EXperiments (ChArMEx) (ACP/AMT inter-journal SI)". It is not associated with a conference.

Acknowledgements. This study was supported by ChArMEx, ENVI-MED, ACTRIS-2 (European Union's Horizon 2020 research and innovation programme, grant agreement no. 654109), CEA and CNRS. The authors would like to thank Nikolaos Mihalopoulos for his help in the establishment of the CAO observatory; François Dulac and Eric Hamonou for managing the ChArMEx project with enthusiasm. The present work is a contribution to the Labex CaPPA (Chemical and Physical Properties of the Atmosphere) funded by the French National Research Agency (ANR-11-LABX-005-01) and the European Funds for Regional Economic Development (FEDER). The Hauts-de-France Regional Council, the French Ministry for Higher Education and Research, and the FEDER are also acknowledged for their financial support through the CPER research project CLIMIBIO (changement climatique, dynamique de l'atmosphère, impacts sur la biodiversité et la santé humaine).

Edited by: Matthias Beekmann

Reviewed by: two anonymous referees

\section{References}

ACTRIS Measurement Guidelines VOC: WP4-NA4: Trace gases networking: Volatile organic carbon and nitrogen oxides Deliverable D4.9: Final SOPs for VOCs measurements, available at: http://www.actris.net/Portals/97/Publications/qualitystandards/ WP4_D4.9_M42_30092014.pdf (last access: 5 October 2016), 2014.

Ait-Helal, W., Borbon, A., Sauvage, S., de Gouw, J. A., Colomb, A., Gros, V., Freutel, F., Crippa, M., Afif, C., Baltensperger, U., Beekmann, M., Doussin, J.-F., Durand-Jolibois, R., Fronval, I., Grand, N., Leonardis, T., Lopez, M., Michoud, V., Miet, K., Perrier, S., Prévôt, A. S. H., Schneider, J., Siour, G., Zapf, P., and Locoge, N.: Volatile and intermediate volatility organic compounds in suburban Paris: variability, origin and importance for SOA formation, Atmos. Chem. Phys., 14, 10439-10464, https://doi.org/10.5194/acp-14-10439-2014, 2014.

Ashbaugh, L. L., Malm, W. C., and Sadeh, W. Z.: A residence time probability analysis of sulfur concentrations at grand Canyon National Park, Atmos. Environ., 1967, 19, 1263-1270, https://doi.org/10.1016/0004-6981(85)90256-2, 1985.

Atkinson, R.: Atmospheric chemistry of $\mathrm{VOCs}$ and $\mathrm{NO}_{x}$, Atmos. Environ., 34, 2063-2101, https://doi.org/10.1016/S13522310(99)00460-4, 2000.

Atkinson, R. and Arey, J.: Atmospheric degradation of volatile organic compounds, Chem. Rev., 103, 4605-4638, https://doi.org/10.1021/cr0206420, 2003.

Aumont, B., Szopa, S., and Madronich, S.: Modelling the evolution of organic carbon during its gas-phase tropospheric oxidation: development of an explicit model based on a self generating approach, Atmos. Chem. Phys., 5, 2497-2517, https://doi.org/10.5194/acp-5-2497-2005, 2005.

Aumont, B., Valorso, R., Mouchel-Vallon, C., Camredon, M., Lee-Taylor, J., and Madronich, S.: Modeling SOA formation from the oxidation of intermediate volatility $n$-alkanes, Atmos. Chem. Phys., 12, 7577-7589, https://doi.org/10.5194/acp-127577-2012, 2012.

Badol, C., Locoge, N., and Galloo, J.-C.: Using a sourcereceptor approach to characterise VOC behaviour in a French urban area influenced by industrial emissions: Part II: Source contribution assessment using the Chemical Mass Balance (CMB) model, Sci. Total Environ., 389, 429-440, https://doi.org/10.1016/j.scitotenv.2007.09.002, 2008.

Baudic, A., Gros, V., Sauvage, S., Locoge, N., Sanchez, O., SardaEstève, R., Kalogridis, C., Petit, J.-E., Bonnaire, N., Baisnée, D., Favez, O., Albinet, A., Sciare, J., and Bonsang, B.: Seasonal variability and source apportionment of volatile organic compounds (VOCs) in the Paris megacity (France), Atmos. Chem. Phys., 16, 11961-11989, https://doi.org/10.5194/acp-16-119612016, 2016.

Blake, R. S., Monks, P. S., and Ellis, A. M.: Proton-transfer reaction mass spectrometry, Chem. Rev., 109, 861-896, https://doi.org/10.1021/cr800364q, 2009.

Bougiatioti, A., Stavroulas, I., Kostenidou, E., Zarmpas, P., Theodosi, C., Kouvarakis, G., Canonaco, F., Prévôt, A. S. H., Nenes, A., Pandis, S. N., and Mihalopoulos, N.: Processing of biomass-burning aerosol in the eastern Mediterranean during summertime, Atmos. Chem. Phys., 14, 4793-4807, https://doi.org/10.5194/acp-14-4793-2014, 2014. 
Bressi, M., Sciare, J., Ghersi, V., Mihalopoulos, N., Petit, J.-E., Nicolas, J. B., Moukhtar, S., Rosso, A., Féron, A., Bonnaire, N., Poulakis, E., and Theodosi, C.: Sources and geographical origins of fine aerosols in Paris (France), Atmos. Chem. Phys., 14, 8813-8839, https://doi.org/10.5194/acp-14-8813-2014, 2014.

Brown, S. G., Eberly, S., Paatero, P., and Norris, G. A.: Methods for estimating uncertainty in PMF solutions: Examples with ambient air and water quality data and guidance on reporting PMF results, Sci. Total Environ., 518-519, 626-635, https://doi.org/10.1016/j.scitotenv.2015.01.022, 2015.

Charron, A., Plaisance, H., Sauvage, S., Coddeville, P., Galloo, J.-C., and Guillermo, R.: A study of the source-receptor relationships influencing the acidity of precipitation collected at a rural site in France, Atmos. Environ., 34, 3665-3674, https://doi.org/10.1016/S1352-2310(00)00096-0, 2000.

Clements, N., Hannigan, M. P., Miller, S. L., Peel, J. L., and Milford, J. B.: Comparisons of urban and rural $\mathrm{PM}_{10-2.5}$ and $\mathrm{PM}_{2.5}$ mass concentrations and semi-volatile fractions in northeastern Colorado, Atmos. Chem. Phys., 16, 7469-7484, https://doi.org/10.5194/acp-16-7469-2016, 2016.

Davison, B., Taipale, R., Langford, B., Misztal, P., Fares, S., Matteucci, G., Loreto, F., Cape, J. N., Rinne, J., and Hewitt, C. N.: Concentrations and fluxes of biogenic volatile organic compounds above a Mediterranean macchia ecosystem in western Italy, Biogeosciences, 6, 1655-1670, https://doi.org/10.5194/bg6-1655-2009, 2009.

de Gouw, J. A., Middlebrook, A. M., Warneke, C., Goldan, P. D., Kuster, W. C., Roberts, J. M., Fehsenfeld, F. C., Worsnop, D. R., Canagaratna, M. R., Pszenny, A. A. P., Keene, W. C., Marchewka, M., Bertman, S. B., and Bates, T. S.: Budget of organic carbon in a polluted atmosphere: Results from the New England Air Quality Study in 2002, J. Geophys. Res., 110, D16305, https://doi.org/10.1029/2004JD005623, 2005.

de Gouw, J. and Warneke, C.: Measurements of volatile organic compounds in the earth's atmosphere using proton-transferreaction mass spectrometry, Mass Spectrom. Rev., 26, 223-257, https://doi.org/10.1002/mas.20119, 2007.

Derstroff, B., Hüser, I., Bourtsoukidis, E., Crowley, J. N., Fischer, H., Gromov, S., Harder, H., Janssen, R. H. H., Kesselmeier, J., Lelieveld, J., Mallik, C., Martinez, M., Novelli, A., Parchatka, U., Phillips, G. J., Sander, R., Sauvage, C., Schuladen, J., Stönner, C., Tomsche, L., and Williams, J.: Volatile organic compounds (VOCs) in photochemically aged air from the eastern and western Mediterranean, Atmos. Chem. Phys., 17, 9547-9566, https://doi.org/10.5194/acp-17-9547-2017, 2017.

Detournay, A., Sauvage, S., Locoge, N., Gaudion, V., Leonardis, T., Fronval, I., Kaluzny, P., and Galloo, J.-C.: Development of a sampling method for the simultaneous monitoring of straightchain alkanes, straight-chain saturated carbonyl compounds and monoterpenes in remote areas, J. Environ. Monitor., 13, 983990, https://doi.org/10.1039/C0EM00354A, 2011.

Detournay, A., Sauvage, S., Riffault, V., Wroblewski, A., and Locoge, N.: Source and behavior of isoprenoid compounds at a southern France remote site, Atmos. Environ., 77, 272-282, https://doi.org/10.1016/j.atmosenv.2013.03.041, 2013.

DLI: Cyprus Informative Inventory Report 2014, Inventories of Cyprus, Ministry of Labour, Welfare and Social Insurance Department of Labour Inspection, Nicosia,
Cyprus, available at: http://cdr.eionet.europa.eu/cy/un/UNECE_ CLRTAP_CY/envvufm9w, last access: 7 July 2016.

Doche, C., Dufour, G., Foret, G., Eremenko, M., Cuesta, J., Beekmann, M., and Kalabokas, P.: Summertime troposphericozone variability over the Mediterranean basin observed with IASI, Atmos. Chem. Phys., 14, 10589-10600, https://doi.org/10.5194/acp-14-10589-2014, 2014.

Dolgorouky, C.: Mesure de la réactivité atmosphérique totale avec les radicaus hydroxyles $(\mathrm{OH})$ ?: developpements et applications en Ile-de-France, Université Paris Sud - Paris XI, available at: https://tel.archives-ouvertes.fr/tel-00684758 (last access: 17 February 2015), 2012.

Draxler, R. R. and Hess, G. D.: Description of the HYSPLIT_4 modeling system. NOAA Tech. Memo, ERL ARL-224 NOAA Air Resour. Lab., Silver Spring, 24 pp., 1997.

Dulac, F.: An overview of the Chemistry-Aerosol Mediterranean Experiment (ChArMEx), Geophysical Research Abstracts EGU General Assembly 2014, vol. 16, p. 11441, 2014.

Ellison, S. L. R. and Williams, A. (Eds.): Eurachem/CITAC guide: Quantifying Uncertainty in Analytical Measurement, Third Edn., ISBN 978-0-948926-30-3, available from: www.eurachem.org (last access: 5 October 2016), 2012.

Fall, P. L.: Modern vegetation, pollen and climate relationships on the Mediterranean island of Cyprus, Rev. Palaeobot. Palyno., 185, 79-92, https://doi.org/10.1016/j.revpalbo.2012.08.002, 2012.

Finlayson-Pitts, B. J. and Pitts, J. N.: Chemistry of the Upper and Lower Atmosphere Theory, Experiments, and Applications, Academic Press, available at: http://www.sciencedirect.com/science/ book/9780122570605 (last access: 25 August 2016), 2000.

Fountoukis, C., Racherla, P. N., Denier van der Gon, H. A. C., Polymeneas, P., Charalampidis, P. E., Pilinis, C., Wiedensohler, A., Dall'Osto, M., O'Dowd, C., and Pandis, S. N.: Evaluation of a three-dimensional chemical transport model (PMCAMx) in the European domain during the EUCAARI May 2008 campaign, Atmos. Chem. Phys., 11, 10331-10347, https://doi.org/10.5194/acp-11-10331-2011, 2011.

Friedrich, R., Obermeier, A., and Hewitt, C. N.: Anthropogenic emissions of volatile organic compounds, in: Reactive Hydrocarbons in the Atmosphere, Academic Press, San Diego, CA, USA, 1999.

Fuzzi, S., Andreae, M. O., Huebert, B. J., Kulmala, M., Bond, T. C., Boy, M., Doherty, S. J., Guenther, A., Kanakidou, M., Kawamura, K., Kerminen, V.-M., Lohmann, U., Russell, L. M., and Pöschl, U.: Critical assessment of the current state of scientific knowledge, terminology, and research needs concerning the role of organic aerosols in the atmosphere, climate, and global change, Atmos. Chem. Phys., 6, 2017-2038, https://doi.org/10.5194/acp-6-2017-2006, 2006.

Gaimoz, C., Sauvage, S., Gros, V., Herrmann, F., Williams, J., Locoge, N., Perrussel, O., Bonsang, B., d'Argouges, O., SardaEstève, R., and Sciare, J.: Volatile organic compounds sources in Paris in spring 2007. Part II: source apportionment using positive matrix factorisation, Environ. Chem., 8, 91-103, 2011.

Geron, C., Guenther, A., Sharkey, T., and Arnts, R. R.: Temporal variability in basal isoprene emission factor, Tree Physiol., 20, 799-805, 2000.

Giorgi, F.: Climate change hot-spots, Geophys. Res. Lett., 33, L08707, https://doi.org/10.1029/2006GL025734, 2006. 
Goldstein, A. H. and Galbally, I. E.: Known and unexplored organic constituents in the earth's atmosphere, Environ. Sci. Technol., 41, 1514-1521, https://doi.org/10.1021/es072476p, 2007.

Goldstein, A. H. and Schade, G. W.: Quantifying biogenic and anthropogenic contributions to acetone mixing ratios in a rural environment, Atmos. Environ., 34, 4997-5006, https://doi.org/10.1016/S1352-2310(00)00321-6, 2000.

Gros, V., Sciare, J., and Yu, T.: Air-quality measurements in megacities: Focus on gaseous organic and particulate pollutants and comparison between two contrasted cities, Paris and Beijing, Impact Chang. Clim. Glob. Sur Qual. Air À Léchelle Régionale, C. R. Geosci., 339, 764-774, https://doi.org/10.1016/j.crte.2007.08.007, 2011.

Guenther, A., Geron, C., Pierce, T., Lamb, B., Harley, P., and Fall, R.: Natural emissions of non-methane volatile organic compounds, carbon monoxide, and oxides of nitrogen from North America, Atmos. Environ., 34, 2205-2230, https://doi.org/10.1016/S1352-2310(99)00465-3, 2000.

Guo, H., So, K. L., Simpson, I. J., Barletta, B., Meinardi, S., and Blake, D. R.: C1-C8 volatile organic compounds in the atmosphere of Hong Kong: overview of atmospheric processing and source apportionment, Atmos. Environ., 41, 1456-1472, https://doi.org/10.1016/j.atmosenv.2006.10.011, 2007.

Harrison, D., Hunter, M., Lewis, A., Seakins, P., Nunes, T., and Pio, C.: Isoprene and monoterpene emission from the coniferous species Abies Borisii-regis - implications for regional air chemistry in Greece, Atmos. Environ., 35, 4687-4698, https://doi.org/10.1016/S1352-2310(01)00092-9, 2001.

Hellén, H., Hakola, H., and Laurila, T.: Determination of source contributions of NMHCs in Helsinki $\left(60^{\circ} \mathrm{N}, 25^{\circ} \mathrm{E}\right)$ using chemical mass balance and the Unmix multivariate receptor models, Atmos. Environ., 37, 1413-1424, https://doi.org/10.1016/S13522310(02)01049-X, 2003.

Hopke, P. K.: Recent developments in receptor modeling, J. Chemometr., 17, 255-265, https://doi.org/10.1002/cem.796, 2003.

Im, U. and Kanakidou, M.: Impacts of East Mediterranean megacity emissions on air quality, Atmos. Chem. Phys., 12, 6335-6355, https://doi.org/10.5194/acp-12-6335-2012, 2012.

Jacob, D. J., Field, B. D., Jin, E. M., Bey, I., Li, Q., Logan, J. A., Yantosca, R. M., and Singh, H. B.: Atmospheric budget of acetone, J. Geophys. Res.-Atmos., 107, ACH 5-1, https://doi.org/10.1029/2001JD000694, 2002.

Janson, R. and de Serves, C.: Acetone and monoterpene emissions from the boreal forest in northern Europe, Atmos. Environ., 35, 4629-4637, https://doi.org/10.1016/S1352-2310(01)001601,2001 .

Jimenez, J. L., Canagaratna, M. R., Donahue, N. M., Prevot, A. S. H., Zhang, Q., Kroll, J. H., DeCarlo, P. F., Allan, J. D., Coe, H., Ng, N. L., Aiken, A. C., Docherty, K. S., Ulbrich, I. M., Grieshop, A. P., Robinson, A. L., Duplissy, J., Smith, J. D., Wilson, K. R., Lanz, V. A., Hueglin, C., Sun, Y. L., Tian, J., Laaksonen, A., Raatikainen, T., Rautiainen, J., Vaattovaara, P., Ehn, M., Kulmala, M., Tomlinson, J. M., Collins, D. R., Cubison, M. J., Dunlea, J., Huffman, J. A., Onasch, T. B., Alfarra, M. R., Williams, P. I., Bower, K., Kondo, Y., Schneider, J., Drewnick, F., Borrmann, S., Weimer, S., Demerjian, K., Salcedo, D., Cottrell, L., Griffin, R., Takami, A., Miyoshi, T., Hatakeyama, S., Shimono, A., Sun, J. Y., Zhang, Y. M., Dzepina, K., Kim- mel, J. R., Sueper, D., Jayne, J. T., Herndon, S. C., Trimborn, A. M., Williams, L. R., Wood, E. C., Middlebrook, A. M., Kolb, C. E., Baltensperger, U., and Worsnop, D. R.: Evolution of organic aerosols in the atmosphere, Science, 326, 1525, https://doi.org/10.1126/science.1180353, 2009.

Jorquera, H. and Rappenglück, B.: Receptor modeling of ambient VOC at Santiago, Chile, Atmos. Environ., 38, 4243-4263, https://doi.org/10.1016/j.atmosenv.2004.04.030, 2004.

Kalabokas, P., Bartzis, J. G., Bomboi, T., Ciccioli, P., Cieslik, S., Dlugi, R., Foster, P., Kotzias, D., and Steinbrecher, R.: BEMA: A European Commision Project on Biogenic Emmissions in the Mediterranean AreaAmbient atmospheric trace gas concentrations and meteorological parameters during the first BEMA measuring campaign on May 1994 at Castelporziano, Italy, Atmos. Environ., 31, 67-77, https://doi.org/10.1016/S13522310(97)00075-7, 1997.

Kalogridis, A.-C.: Caractérisation des composées organiques volatils en région méditerranéenne, Université Paris Sud - Paris XI, 2014.

Kalogridis, C., Gros, V., Sarda-Esteve, R., Langford, B., Loubet, B., Bonsang, B., Bonnaire, N., Nemitz, E., Genard, A.-C., Boissard, C., Fernandez, C., Ormeño, E., Baisnée, D., Reiter, I., and Lathière, J.: Concentrations and fluxes of isoprene and oxygenated VOCs at a French Mediterranean oak forest, Atmos. Chem. Phys., 14, 10085-10102, https://doi.org/10.5194/acp-14-100852014, 2014.

Kanakidou, M., Seinfeld, J. H., Pandis, S. N., Barnes, I., Dentener, F. J., Facchini, M. C., Van Dingenen, R., Ervens, B., Nenes, A., Nielsen, C. J., Swietlicki, E., Putaud, J. P., Balkanski, Y., Fuzzi, S., Horth, J., Moortgat, G. K., Winterhalter, R., Myhre, C. E. L., Tsigaridis, K., Vignati, E., Stephanou, E. G., and Wilson, J.: Organic aerosol and global climate modelling: a review, Atmos. Chem. Phys., 5, 1053-1123, https://doi.org/10.5194/acp-5-10532005, 2005.

Kanakidou, M., Mihalopoulos, N., Kindap, T., Im, U., Vrekoussis, M., Gerasopoulos, E., Dermitzaki, E., Unal, A., Koçak, M., Markakis, K., Melas, D., Kouvarakis, G., Youssef, A. F., Richter, A., Hatzianastassiou, N., Hilboll, A., Ebojie, F., Wittrock, F., von Savigny, C., Burrows, J. P., LadstaetterWeissenmayer, A., and Moubasher, H.: Megacities as hot spots of air pollution in the East Mediterranean, Atmos. Environ., 45, 1223-1235, https://doi.org/10.1016/j.atmosenv.2010.11.048, 2011.

Kim, E., Hopke, P. K., and Edgerton, E. S.: Source identification of Atlanta aerosol by positive matrix factorization, J. Air Waste Manage., 53, 731-739, https://doi.org/10.1080/10473289.2003.10466209, 2003.

Kim, E., Brown, S. G., Hafner, H. R., and Hopke, P. K.: Characterization of non-methane volatile organic compounds sources in Houston during 2001 using positive matrix factorization, Atmos. Environ., 39, 5934-5946, https://doi.org/10.1016/j.atmosenv.2005.06.045, 2005.

Kleanthous, S., Vrekoussis, M., Mihalopoulos, N., Kalabokas, P., and Lelieveld, J.: On the temporal and spatial variation of ozone in Cyprus, Sci. Total Environ., 476-477, 677-687, https://doi.org/10.1016/j.scitotenv.2013.12.101, 2014.

Kopf, S.: Development and Climate Change - World Development Report 2010, The World Bank, available at: https://siteresources.worldbank.org/INTWDR2010/Resources/ 
5287678-1226014527953/WDR10-Full-Text.pdf (last access: 12 May 2015), 2010.

Kroll, J. H. and Seinfeld, J. H.: Chemistry of secondary organic aerosol: Formation and evolution of low-volatility organics in the atmosphere, Atmos. Environ., 42, 3593-3624, https://doi.org/10.1016/j.atmosenv.2008.01.003, 2008.

Lanz, V. A., Hueglin, C., Buchmann, B., Hill, M., Locher, R., Staehelin, J., and Reimann, S.: Receptor modeling of $\mathrm{C}_{2}-\mathrm{C}_{7}$ hydrocarbon sources at an urban background site in Zurich, Switzerland: changes between 1993-1994 and 2005-2006, Atmos. Chem. Phys., 8, 2313-2332, https://doi.org/10.5194/acp-82313-2008, 2008.

Laothawornkitkul, J., Taylor, J. E., Paul, N. D., and Hewitt, C. N.: Biogenic volatile organic compounds in the Earth system, New Phytol., 183, 27-51, https://doi.org/10.1111/j.14698137.2009.02859.x, 2009.

Legreid, G., Lööv, J. B., Staehelin, J., Hueglin, C., Hill, M., Buchmann, B., Prevot, A. S. H., and Reimann, S.: Oxygenated volatile organic compounds (OVOCs) at an urban background site in Zürich (Europe): seasonal variation and source allocation, Atmos. Environ., 41, 8409-8423, https://doi.org/10.1016/j.atmosenv.2007.07.026, 2007.

Lelieveld, J., Berresheim, H., Borrmann, S., Crutzen, P. J., Dentener, F. J., Fischer, H., Feichter, J., Flatau, P. J., Heland, J., Holzinger, R., Korrmann, R., Lawrence, M. G., Levin, Z., Markowicz, K. M., Mihalopoulos, N., Minikin, A., Ramanathan, V., de Reus, M., Roelofs, G. J., Scheeren, H. A., Sciare, J., Schlager, H., Schultz, M., Siegmund, P., Steil, B., Stephanou, E. G., Stier, P., Traub, M., Warneke, C., Williams, J., and Ziereis, H.: Global air pollution crossroads over the Mediterranean, Science, 298, 794-799, 2002.

Lelieveld, J., Hadjinicolaou, P., Kostopoulou, E., Giannakopoulos, C., Pozzer, A., Tanarhte, M., and Tyrlis, E.: Model projected heat extremes and air pollution in the eastern Mediterranean and Middle East in the twenty-first century, Reg. Environ. Change, 14, 1937-1949, https://doi.org/10.1007/s10113013-0444-4, 2014.

Leuchner, M., Gubo, S., Schunk, C., Wastl, C., Kirchner, M., Menzel, A., and Plass-Dülmer, C.: Can positive matrix factorization help to understand patterns of organic trace gases at the continental Global Atmosphere Watch site Hohenpeissenberg?, Atmos. Chem. Phys., 15, 1221-1236, https://doi.org/10.5194/acp15-1221-2015, 2015.

Liakakou, E., Vrekoussis, M., Bonsang, B., Donousis, C., Kanakidou, M., and Mihalopoulos, N.: Isoprene above the Eastern Mediterranean: Seasonal variation and contribution to the oxidation capacity of the atmosphere, Atmos. Environ., 41, 10021010, 2007.

Liakakou, E., Bonsang, B., Williams, J., Kalivitis, N., Kanakidou, M., and Mihalopoulos, N.: C2-C8 NMHCs over the Eastern Mediterranean: Seasonal variation and impact on regional oxidation chemistry, Atmos. Environ., 43, 5611-5621, https://doi.org/10.1016/j.atmosenv.2009.07.067, 2009.

Lo Vullo, E., Furlani, F., Arduini, J., Giostra, U., Graziosi, F., Cristofanelli, P., Williams, M. L., and Maione, M.: Anthropogenic non-methane volatile hydrocarbons at Mt. Cimone (2165 ma.s.l., Italy): Impact of sources and transport on atmospheric composition, Atmos. Environ., 140, 395-403, https://doi.org/10.1016/j.atmosenv.2016.05.060, 2016.
Madronich, S.: Chemical evolution of gaseous air pollutants down-wind of tropical megacities: Mexico City case study, Atmos. Environ., 40, 6012-6018, https://doi.org/10.1016/j.atmosenv.2005.08.047, 2006.

Menut, L., Rea, G., Mailler, S., Khvorostyanov, D., and Turquety, S.: Aerosol forecast over the Mediterranean area during July 2013 (ADRIMED/CHARMEX), Atmos. Chem. Phys., 15, 78977911, https://doi.org/10.5194/acp-15-7897-2015, 2015.

Michoud, V., Sciare, J., Sauvage, S., Dusanter, S., Léonardis, T., Gros, V., Kalogridis, C., Zannoni, N., Féron, A., Petit, J.-E., Crenn, V., Baisnée, D., Sarda-Estève, R., Bonnaire, N., Marchand, N., DeWitt, H. L., Pey, J., Colomb, A., Gheusi, F., Szidat, S., Stavroulas, I., Borbon, A., and Locoge, N.: Organic carbon at a remote site of the western Mediterranean Basin: sources and chemistry during the ChArMEx SOP2 field experiment, Atmos. Chem. Phys., 17, 8837-8865, https://doi.org/10.5194/acp17-8837-2017, 2017.

Millet, D. B., Guenther, A., Siegel, D. A., Nelson, N. B., Singh, H. B., de Gouw, J. A., Warneke, C., Williams, J., Eerdekens, G., Sinha, V., Karl, T., Flocke, F., Apel, E., Riemer, D. D., Palmer, P. I., and Barkley, M.: Global atmospheric budget of acetaldehyde: 3-D model analysis and constraints from in-situ and satellite observations, Atmos. Chem. Phys., 10, 3405-3425, https://doi.org/10.5194/acp-10-3405-2010, 2010.

Moschonas, N. and Glavas, S.: Non-methane hydrocarbons at a high-altitude rural site in the Mediterranean (Greece), Atmos. Environ., 34, 973-984, https://doi.org/10.1016/S13522310(99)00205-8, 2000.

Nabat, P., Somot, S., Mallet, M., Chiapello, I., Morcrette, J. J., Solmon, F., Szopa, S., Dulac, F., Collins, W., Ghan, S., Horowitz, L. W., Lamarque, J. F., Lee, Y. H., Naik, V., Nagashima, T., Shindell, D., and Skeie, R.: A 4-D climatology (1979-2009) of the monthly tropospheric aerosol optical depth distribution over the Mediterranean region from a comparative evaluation and blending of remote sensing and model products, Atmos. Meas. Tech., 6, 1287-1314, https://doi.org/10.5194/amt-6-1287-2013, 2013.

Navazo, M., Durana, N., Alonso, L., Gómez, M. C., García, J. A., Ilardia, J. L., Gangoiti, G., and Iza, J.: High temporal resolution measurements of ozone precursors in a rural background station. A two-year study, Environ. Monit. Assess., 136, 53-68, https://doi.org/10.1007/s10661-007-9720-4, 2008.

Ng, N. L., Herndon, S. C., Trimborn, A., Canagaratna, M. R., Croteau, P. L., Onasch, T. B., Sueper, D., Worsnop, D. R., Zhang, Q., Sun, Y. L., and Jayne, J. T.: An Aerosol Chemical Speciation Monitor (ACSM) for routine monitoring of the composition and mass concentrations of ambient aerosol, Aerosol Sci. Tech., 45, 780-794, https://doi.org/10.1080/02786826.2011.560211, 2011.

Niinemets, Ü., Loreto, F., and Reichstein, M.: Physiological and physicochemical controls on foliar volatile organic compound emissions, Trends Plant Sci., 9, 180-186, https://doi.org/10.1016/j.tplants.2004.02.006, 2004.

Norris, G., Duvall, R., Brown, S., and Bai, S.: EPA Positive Matrix Factorization (PMF) 5.0 fundamentals and User Guide Prepared for the US Environmental Protection Agency Office of Research and Development, Washington, DC, by the National Exposure Research Laboratory, Research Triangle Park, Sonoma Technology, Inc., Petaluma, 2014. 
Owen, S., Boissard, C., Street, R. A., Duckham, S. C., Csiky, O., and Hewitt, C. N.: Screening of 18 Mediterranean plant species for volatile organic compound emissions, Atmos. Environ., 31, 101-117, https://doi.org/10.1016/S1352-2310(97)00078-2, 1997.

Owen, S. M., Boissard, C., and Hewitt, C. N.: Volatile organic compounds (VOCs) emitted from 40 Mediterranean plant species:: VOC speciation and extrapolation to habitat scale, Atmos. Environ., 35, 5393-5409, 2001.

Paatero, P.: Least squares formulation of robust non-negative factor analysis, Chemometr. Intell. Lab., 37, 23-35, https://doi.org/10.1016/S0169-7439(96)00044-5, 1997.

Paatero, P.: The Multilinear Engine - a table-driven, least squares program for solving multilinear problems, including the $n$-Way Parallel Factor Analysis Model, J. Comput. Graph. Stat., 8, 854888, https://doi.org/10.1080/10618600.1999.10474853, 1999.

Paatero, P. and Tapper, U.: Positive matrix factorization: A non-negative factor model with optimal utilization of error estimates of data values, Environmetrics, 5, 111-126, https://doi.org/10.1002/env.3170050203, 1994.

Paatero, P., Hopke, P. K., Song, X.-H., and Ramadan, Z.: Understanding and controlling rotations in factor analytic models, Chemometr. Intell. Lab., 60, 253-264, https://doi.org/10.1016/S0169-7439(01)00200-3, 2002.

Paatero, P., Eberly, S., Brown, S. G., and Norris, G. A.: Methods for estimating uncertainty in factor analytic solutions, Atmos. Meas. Tech., 7, 781-797, https://doi.org/10.5194/amt-7781-2014, 2014.

Paatero, P., Hopke, P. K., Begum, B. A., and Biswas, S. K.: A graphical diagnostic method for assessing the rotation in factor analytical models of atmospheric pollution, Atmos. Environ., 39, 193201, https://doi.org/10.1016/j.atmosenv.2004.08.018, 2005.

Pace, G., di Sarra, A., Meloni, D., Piacentino, S., and Chamard, P.: Aerosol optical properties at Lampedusa (Central Mediterranean). 1. Influence of transport and identification of different aerosol types, Atmos. Chem. Phys., 6, 697-713, https://doi.org/10.5194/acp-6-697-2006, 2006.

Patashnick, H. and Rupprecht, E. G.: Continuous PM10 measurements using the tapered element oscillating microbalance, J. Air Waste Manag., 41, 1079-1083, https://doi.org/10.1080/10473289.1991.10466903, 1991.

Petit, J.-E., Favez, O., Sciare, J., Crenn, V., Sarda-Estève, R., Bonnaire, N., Močnik, G., Dupont, J.-C., Haeffelin, M., and LeozGarziandia, E.: Two years of near real-time chemical composition of submicron aerosols in the region of Paris using an Aerosol Chemical Speciation Monitor (ACSM) and a multiwavelength Aethalometer, Atmos. Chem. Phys., 15, 2985-3005, https://doi.org/10.5194/acp-15-2985-2015, 2015.

Petit, J.-E., Favez, O., Albinet, A., and Canonaco, F.: A userfriendly tool for comprehensive evaluation of the geographical origins of atmospheric pollution: Wind and trajectory analyses, Environ. Model. Softw., 88, 183-187, https://doi.org/10.1016/j.envsoft.2016.11.022, 2017.

Polissar, A. V., Hopke, P. K., Paatero, P., Malm, W. C., and Sisler, J. F.: Atmospheric aerosol over Alaska: 2. Elemental composition and sources, J. Geophys. Res.-Atmos., 103, 1904519057, https://doi.org/10.1029/98JD01212, 1998.

Safieddine, S., Boynard, A., Coheur, P.-F., Hurtmans, D., Pfister, G., Quennehen, B., Thomas, J. L., Raut, J.-C., Law, K. S.,
Klimont, Z., Hadji-Lazaro, J., George, M., and Clerbaux, C.: Summertime tropospheric ozone assessment over the Mediterranean region using the thermal infrared IASI/MetOp sounder and the WRF-Chem model, Atmos. Chem. Phys., 14, 1011910131, https://doi.org/10.5194/acp-14-10119-2014, 2014.

Salameh, T., Afif, C., Sauvage, S., Borbon, A., and Locoge, N.: Speciation of non-methane hydrocarbons (NMHCs) from anthropogenic sources in Beirut, Lebanon, Environ. Sci. Pollut., 21, 10867-10877, https://doi.org/10.1007/s11356-014-2978-5, 2014.

Salameh, T., Sauvage, S., Afif, C., Borbon, A., and Locoge, N.: Source apportionment vs. emission inventories of non-methane hydrocarbons (NMHC) in an urban area of the Middle East: local and global perspectives, Atmos. Chem. Phys., 16, 3595-3607, https://doi.org/10.5194/acp-16-3595-2016, 2016.

Sandradewi, J., Prévôt, A. S. H., Szidat, S., Perron, N., Alfarra, M. R., Lanz, V. A., Weingartner, E., and Baltensperger, U.: Using aerosol light absorption measurements for the quantitative determination of wood burning and traffic emission contributions to particulate matter, Environ. Sci. Technol., 42, 33163323, https://doi.org/10.1021/es702253m, 2008.

Sauvage, S., Plaisance, H., Locoge, N., Wroblewski, A., Coddeville, P., and Galloo, J. C.: Long term measurement and source apportionment of non-methane hydrocarbons in three French rural areas, Atmos. Environ., 43, 2430-2441, https://doi.org/10.1016/j.atmosenv.2009.02.001, 2009.

Schade, G., Solomon, S., Dellwik, E., Pilegaard, K., and LadstätterWeissenmayer, A.: Methanol and other VOC fluxes from a Danish beech forest during late springtime, Biogeochemistry, 106, 337-355, https://doi.org/10.1007/s10533-010-9515-5, 2011.

Schade, G. W. and Goldstein, A. H.: Fluxes of oxygenated volatile organic compounds from a ponderosa pine plantation, J. Geophys. Res.-Atmos., 106, 3111-3123, https://doi.org/10.1029/2000JD900592, 2001.

Sciare, J.: The Agia Marina Xyliatou Observatory: A remote supersite in Cyprus to monitor changes in the atmospheric composition of the Eastern Mediterranean and the Middle East, Geophysical Research Abstracts - EGU General Assembly 2016, 18, 11493, 2016.

Seco, R., Peñuelas, J., and Filella, I.: Short-chain oxygenated VOCs: Emission and uptake by plants and atmospheric sources, sinks, and concentrations, Atmos. Environ., 41, 2477-2499, https://doi.org/10.1016/j.atmosenv.2006.11.029, 2007.

Seco, R., Peñuelas, J., Filella, I., Llusià, J., Molowny-Horas, R., Schallhart, S., Metzger, A., Müller, M., and Hansel, A.: Contrasting winter and summer VOC mixing ratios at a forest site in the Western Mediterranean Basin: the effect of local biogenic emissions, Atmos. Chem. Phys., 11, 13161-13179, https://doi.org/10.5194/acp-11-13161-2011, 2011.

Seibert, P., Kromp-Kolb, H., Baltensperger, U., Jost, D., Schwikowski, M., Kasper, A., and Puxbaum, H.: Trajectory analysis of aerosol measurements at high alpine sites, Transp. Transform. Pollut. Troposphere, 15, 689-693, 1994.

Seinfeld, J. N. and Pandis, S. N.: Atmospheric Chemistry Physics: From Air Pollution to Climate Change, Wiley, New York, 1998.

Singh, H. B., Salas, L. J., Chatfield, R. B., Czech, E., Fried, A., Walega, J., Evans, M. J., Field, B. D., Jacob, D. J., Blake, D., Heikes, B., Talbot, R., Sachse, G., Crawford, J. H., Avery, M. A., Sandholm, S., and Fuelberg, H.: Analysis of 
the atmospheric distribution, sources, and sinks of oxygenated volatile organic chemicals based on measurements over the $\mathrm{Pa}$ cific during TRACE-P, J. Geophys. Res.-Atmos., 109, D15S07, https://doi.org/10.1029/2003JD003883, 2004.

Spaulding, R. S., Schade, G. W., Goldstein, A. H., and Charles, M. J.: Characterization of secondary atmospheric photooxidation products: evidence for biogenic and anthropogenic sources, J. Geophys. Res.-Atmos., 108, 4247, https://doi.org/10.1029/2002JD002478, 2003.

Spivakovsky, C. M., Logan, J. A., Montzka, S. A., Balkanski, Y. J., Foreman-Fowler, M., Jones, D. B. A., Horowitz, L. W., Fusco, A. C., Brenninkmeijer, C. A. M., Prather, M. J., Wofsy, S. C., and McElroy, M. B.: Three-dimensional climatological distribution of tropospheric $\mathrm{OH}$ : Update and evaluation, J. Geophys. Res.-Atmos., 105, 8931-8980, https://doi.org/10.1029/1999JD901006, 2000.

Stein, A. F., Draxler, R. R., Rolph, G. D., Stunder, B. J. B., Cohen, M. D., and Ngan, F.: NOAA's HYSPLIT atmospheric transport and dispersion modeling system, B. Am. Meteorol. Soc., 96, 2059-2077, https://doi.org/10.1175/BAMS-D-14$00110.1,2015$.

Stohl, A., Forster, C., Frank, A., Seibert, P., and Wotawa, G.: Technical note: The Lagrangian particle dispersion model FLEXPART version 6.2, Atmos. Chem. Phys., 5, 2461-2474, https://doi.org/10.5194/acp-5-2461-2005, 2005.

Taipale, R., Ruuskanen, T. M., Rinne, J., Kajos, M. K., Hakola, H., Pohja, T., and Kulmala, M.: Technical Note: Quantitative long-term measurements of VOC concentrations by PTR-MS - measurement, calibration, and volume mixing ratio calculation methods, Atmos. Chem. Phys., 8, 6681-6698, https://doi.org/10.5194/acp-8-6681-2008, 2008.

Tsilingiridis, G., Sidiropoulos, C., Pentaliotis, A., Evripidou, C., Papastavros, C., Mesimeris, T., and Papastavrou, M.: A spatially allocated emissions inventory for Cyprus, Global NEST J., 12, 99-107, 2010.

Waked, A., Favez, O., Alleman, L. Y., Piot, C., Petit, J.-E., Delaunay, T., Verlinden, E., Golly, B., Besombes, J.-L., Jaffrezo, J.L., and Leoz-Garziandia, E.: Source apportionment of $\mathrm{PM}_{10}$ in a north-western Europe regional urban background site (Lens, France) using positive matrix factorization and including primary biogenic emissions, Atmos. Chem. Phys., 14, 3325-3346, https://doi.org/10.5194/acp-14-3325-2014, 2014.
Warneke, C., van der Veen, C., Luxembourg, S., de Gouw, J., and Kok, A.: Measurements of benzene and toluene in ambient air using proton-transfer-reaction mass spectrometry: calibration, humidity dependence, and field intercomparison, Int. J. Mass Spectrom., 207, 167-182, https://doi.org/10.1016/S13873806(01)00366-9, 2001.

Xiang, Y., Delbarre, H., Sauvage, S., Léonardis, T., Fourmentin, M., Augustin, P., and Locoge, N.: Development of a methodology examining the behaviours of VOCs source apportionment with micro-meteorology analysis in an urban and industrial area, Environ. Pollut., 162, 15-28, https://doi.org/10.1016/j.envpol.2011.10.012, 2012.

Xie, Y. and Berkowitz, C. M.: The use of positive matrix factorization with conditional probability functions in air quality studies: An application to hydrocarbon emissions in Houston, Texas, Atmos. Environ., 40, 3070-3091, https://doi.org/10.1016/j.atmosenv.2005.12.065, 2006.

Xie, Y. and Berkowitz, C. M.: The use of conditional probability functions and potential source contribution functions to identify source regions and advection pathways of hydrocarbon emissions in Houston, Texas, Atmos. Environ., 41, 5831-5847, https://doi.org/10.1016/j.atmosenv.2007.03.049, 2007.

Yáñez-Serrano, A. M., Nölscher, A. C., Bourtsoukidis, E., Derstroff, B., Zannoni, N., Gros, V., Lanza, M., Brito, J., Noe, S. M., House, E., Hewitt, C. N., Langford, B., Nemitz, E., Behrendt, T., Williams, J., Artaxo, P., Andreae, M. O., and Kesselmeier, J.: Atmospheric mixing ratios of methyl ethyl ketone (2-butanone) in tropical, boreal, temperate and marine environments, Atmos. Chem. Phys., 16, 10965-10984, https://doi.org/10.5194/acp-1610965-2016, 2016.

Yuan, B., Shao, M., de Gouw, J., Parrish, D. D., Lu, S., Wang, M., Zeng, L., Zhang, Q., Song, Y., Zhang, J., and $\mathrm{Hu}, \mathrm{M} .:$ Volatile organic compounds (VOCs) in urban air: how chemistry affects the interpretation of positive matrix factorization (PMF) analysis, J. Geophys. Res.-Atmos., 117, D24302, https://doi.org/10.1029/2012JD018236, 2012.

Zhou, L., Kim, E., Hopke, P. K., Stanier, C. O., and Pandis, S.: Advanced factor analysis on Pittsburgh particle size-distribution data, Aerosol Sci. Tech., 38, 118-132, https://doi.org/10.1080/02786820390229589, 2004. 